GEOLOGICAL SURVEY CIRCULAR 167

\section{Librany Copy}

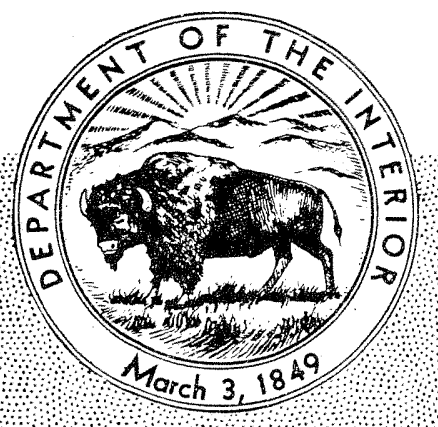

THE RECOVERY OF

GROUND-WATER LEVELS IN

BROOKLYN, NEW YORK

FROM 1947 TO 1950

By Norbert J. Lusczynski 


\author{
UNITED STATES DEPARTMENT OF THE INTERIOR \\ Oscar L. Chapman, Secretary \\ GEOLOGICAL SURVEY \\ W. E. Wrather, Director
}

GEOLOGICAL SURVEY CIRCULAR 167

\title{
THE RECOVERY OF GROUND-WATER LEVELS IN BROOKLYN, NEW YORK, FROM 1947 TO 1950
}

By Norbert J. Lusczynski

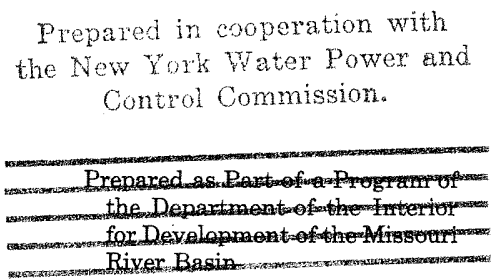

Washington, D. C., 1952

Free on application to the Geological Survey, Washington 25, D. C. 


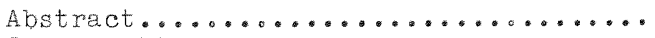

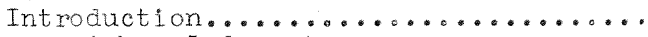

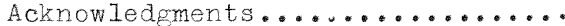

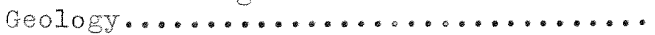

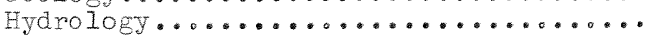

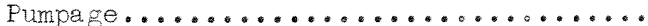

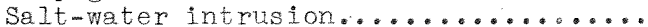
Trend of water-table and artesian

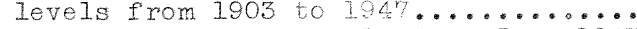
Recovery of water levels from June 1947

to December $1950 \ldots \ldots \ldots \ldots$

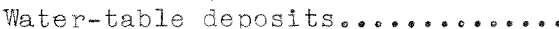

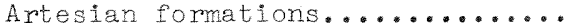

\section{ILLUSTRATIONS}

Summary - recovery of water

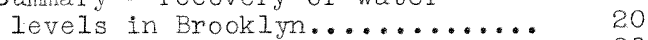

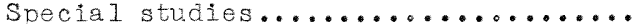

We1Is K523 and K525 in the $\ldots \ldots . . . . . . .20$

Jameco gravel... . . . . . . . . . . .
Well K52I in the Lioyd sand

member of the Raritan forma-

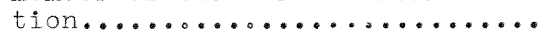

Mutual interference in the

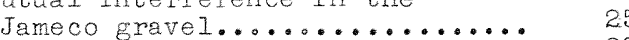

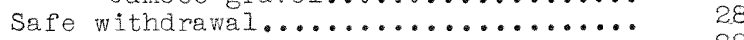

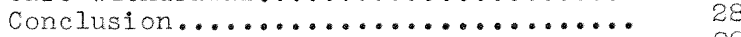

References cited................. 29

Plate 1. Pumpage for public water supply and net withdrawals for industrial

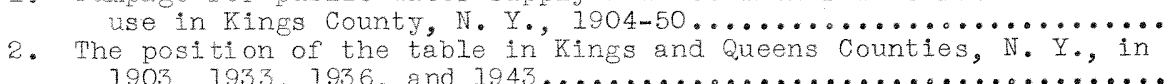

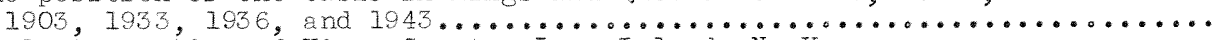

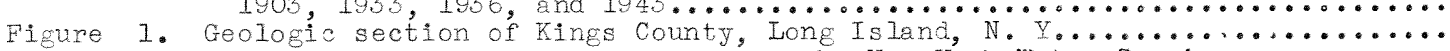

2. Chloride content of ground water in the New York Water Service

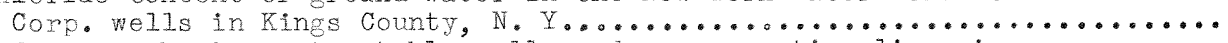

3. Index map showing water-table wejls and cross-section ines in

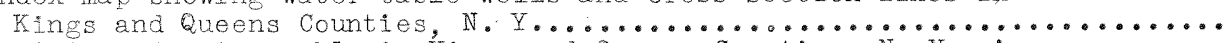

4. Position of water table in Kings and Queens Counties, $N$. $Y$... in

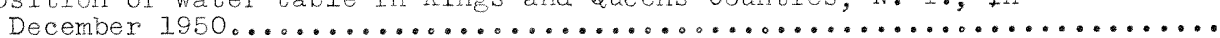

5. Recovery of water table in Kings and cueens counties, $N$. $Y$, from

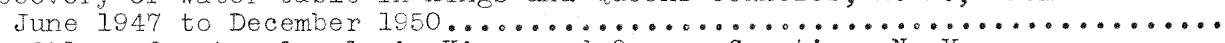

6. Profiles of water levels in Kings and queens Counties, N. Y.,

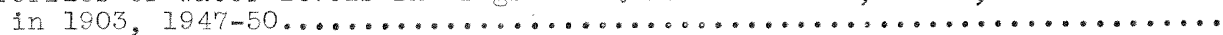

7. Monthly water leveis in selected water-tabie weils on Long Is 1 and,

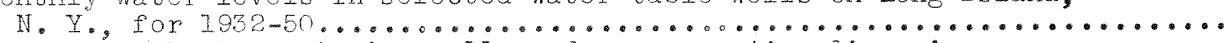

8. Index map showing artesian weils and cross-section ines in

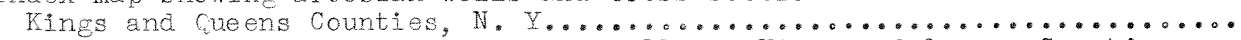

9 . Recovery of water levels in artesian welis in $K$ ings and Queens Counties,

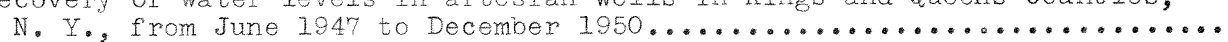

10. Comparison of water levels in water-table and artesian wells in

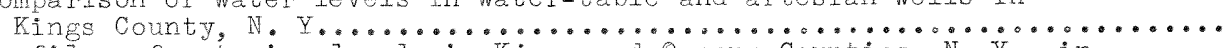

11. Profiles of artesian leveis in Kings and Queens Counties, $N$.

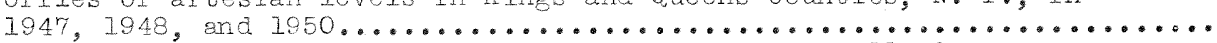

12. Hydrograph showlng monthiy water levels in artesian welis in $\mathrm{K}$ ings and Queens Counties, $\mathrm{N}$. Y., during $1947 \ldots 50 \ldots \ldots \ldots \ldots$

In pocket

In pocket

\section{TABLES}

Table 1. Chloride content of water pumped by the New York Water Service

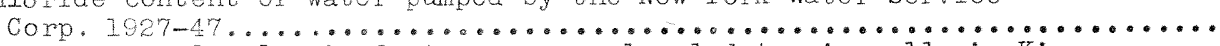

2. Ground-water levels, in feet, mear-sea-level datum in weils in $\mathrm{K} i n g s$ and queens Counties, N. Y. from June 1947 to December $1950 \ldots \ldots$

3. Recovery of ground-water levels, in feet, in Kings and oueens Counties,

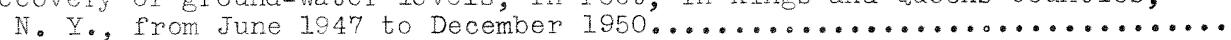

4. Ground-water levels, in feet, mear-sea-level datum, in aditional

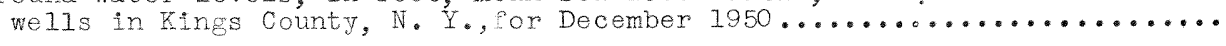

20
20
20
25
25
28
28
29




\section{THE RECOVERY OF GROUND-WATER LEVELS IN BROOKLYN, NEW YORK FROM 1947 TO 1950}

ABST RACT

As a result of condemnation proceedings by the City of New York, the New York Water Service Corp. on June 29-30, 1947, stopped operating permanently its entire ground-water facilities, which served about 350,000 inhabitants in the Flatbush section of Kings County (Borough of Brooklyn in New York City) in westem Long Is land, N. Y. This corporation, operating within the city limits under a franchise granted by the City of New York, was the last and largest of the several private companies that fumished public water supply to residents of Brooklyn during the past $50^{\circ}$ yr or longer. The New York Water Service Corp. utilized as many as 35 wells, which were screened in the shallow water-table formation and in the deeper artesian aquifers lying in its franchise a rea of about $6 \mathrm{sq} \mathrm{mi}$ in the approximate center of Brooklyn.

Withdrawals by this corporation averaged more than 25 mgd during the last $15 \mathrm{yr}$, having increased gradually since 1904 from about 4 mgd. A reduction of more than 50 percent in the net ground-water withdrawals in the county was realized by the shut-down of pumping of the Flatbush wells. As a result the water table, which was far below sea level for many years, recovered as much as $19 \mathrm{ft}$ at some places in central Brooklyn from June 1947 to December 1950. In the artesian aquifers, similar large recoveries in the piezometric levels also were recorded, which likewise had been appreciably below sea level before the shut-down.

Detalled water-level data, contour maps, profiles, and hydrographs of ground-water levels for the period from 1903-50 are presented and discussed in this report. A compilation of the withdrawals by public watersupply companies and industrial concems is included. The geology of Kings County is reviewed in brief. Data on the chloride content of well water, pumped during the last month of operation of wells in Flatbush by the New York Water Service Corp., are given also, and compared with salinities before and after the shut-down. More positive answers to special geologic and mutual-interference problems are made possible by data on the recovery of water levels in westerm Iong Island resulting from the large-scale shut-down of pumping from the water-table and artesian formations.

\section{INTRODUCTION}

The United States Geological Survey has been cooperating since 1932 with the New York State Water Power and Control Commission in making rather intensive studies of the quantity and quality of ground water in westem Iong Island. The program provides for the collection and interpretation of hydrologic data as related to ground-water conditions in Kings and Queens Counties. The main purpose of these investigations is to record and report the trend of water levels as affected by precipitation, pumping, and artificial recharge, and to map periodically the changing position of the water table and of the piezometric levels in the water-bearing formations in westem Long Island. Prior to 1930 , water levels in northwestem Brooklyn had declined to dangerousiy low levels owing to overpumping by industrial and public-supply wells. This condition brought about saltwater contamination in Brooklyn as evidenced by Iong-term records of the saline quality of ground water.

The many data on water levels, chloride content, and pumpage presented in this report were obtained throughout the years as part of the regular ever-expanding cooperative program. However, it was necessary to measure about twice as many wells in Brooklyn from 1947-50 in order to record the recovery of water levels in western Long Is Iand in as much detail and as accurately as possible.

This report was prepared under the general direction of A. N. Sayre, chief of the Ground Water Branch, U. S. Geological Survey, and under the immediate supervision of M. I. Brashears, Jr., district geologist, for New York and New England. The compilation of data, tables, and lilustrations was made with the assistance of the following present and former members attached to the technical staff of the Mineola office of the New York-New England District: J. J. Geraghty, H. D. Wilson, Jr., C. M. Roberts, I. R. Wistoft, J. F. Hof'fman, and Mrs. M. M. Brosge.

\section{Acimowledgments}

The writer expresses his sincere appreclation to Col. T. H. Wiggin, consulting engineer, New York Gity, to whom several 
references are made in this report in comection with previous studies on the ground-water resources in western Long Island. Acknowledgment is made also to John $G$. Thompson, executive engineer, and A. H. Johnson, associate engineer, New York State Water Power and Control Comission who offered many helpful suggestions and constructive criticism.

Many valuable data on withdrawal and salinity of ground water were furnished for this report through the courtesy of the New York Water Service Corp., Jamalca Water Supply Co., and the New York City Department of Water Supply, Gas and Electricity. These organizations allowed members of the U. S. Geological Survey access at all times. to their wells and well stations, and provided physical assistance in the preparation of the wells for the periodic collection of water-level and other recoras. Private owners in westem Long Is land, Including those who purchased property from the New York Water Service Corp. In Flatbush, a Iso permtted water-level measurements to be made at wells on their property.

\section{GEOLOGY}

The geology of western Long Island, particularly that of Brooklyn, wiIl be sketched only briefly here, as it has been discussed at length by De Laguna (1948) and Suter and others (1949).

Long Island is composed of coastel-plain sediments lying unconformably on a floor of metamorphic and igneous rocks of pre-Cambrian age. A considerable thickness of unconsolidated sediments of Upper Cretaceous age is overlain in most places by a relatively thin mantle of outwash and till comprising the upper Pleistocene deposits. The underlying bedrock, which consists chiefly of gneiss and schist, crops out in a small area in northwestern Queens County and slopes to the southeast at about $80 \mathrm{ft}$ to the mile. The lower section of the Cretaceous sediments is considered to be the Raritan formation and is composed of a clay member which overiles ar extensive artesian aquifer called the lloyd sand member. The upper section of the Cretaceous sediments, called the Magothy (?) formation, is largely fine sand interspersed with numerous relatively thin lenges of clay.

In Kings County in westem Iong Island, the Pleistocene deposits rest unconformably on the Cretaceous sediments, except in the northwestem section where these sediments have been removed almost entirely. In this county, the Pleistocene deposits are in general much thicker than the Cretaceous, as shown by the geologic cross section (fig. 1), whereas the opposite is generally true elsewhere on Long Island.

The early glaclal deposits consist of highly permesble water-beaming glacial outwash-whe Jameco gravel-which is overlan by beds of interglacial clay, silt, fine sand ramed Gardiners clay and associated sand. The Jameco gravel overiles the Cretaceous sediments in central and southem Brooklyn and extends to the northwest beyond the limit of the cretaceous. The uppermost and youngest sediments on Lone Island--all those above the Gardiners clay and associated send, with the exception of the very small accumulations of Recent material--consist of glacial outwash and til. The more recent of the two teminal moranes on Long IsLand, the Farbor Hill moralne of Wisconsin age, bisects Brooklyn in a drection approximately northeast to south west. Glacial outwash is found south of the moraine and till north of the moralne. These were recently classifled by De Laguna (1948) in one group as upper Pleistocene deposits.

\section{FYDROLOGY}

Local precipitation, averaging about 45 in. anmuliy, is the source of all fresh eround water in Long Island. The percentage of precipitation recharging ground-water reservoirs in Brooklyn was reduced rapidly during the firgt 25 yr of this century by the works of man-buildings, streets, sidewaIks, and sewers-which paralleled the tremencous increase in population in Kings County and the huge imdustrialization of the northwestem section. The aquifers in Brooklyn are still replenished by precipitation in the county and to some degree by underflow from adjacent Queens county.

In Brooklyn, ground water in the upper Pleistocene deposits occurs chiefly under water-table conditions, although interspersed layers and lenses of clay cause some degree of local confinement, especially in areas north of the Harbor H11 moraine. These PIeistocene deposits are the main source of water supply in Brooklyn. The Jameco gravel is primarily an artesian aquifer, which has circuitous and indirect hydraulic communication with the overlying and underlying aquifers. The interconnection with the upper pleistocene deposits is provided through the interglacial Gardiners clay, which in many sections in Kings County is relatively sandy. The Garainers clay has been removed by erosion in some places. In the southeastem section, where the Jameco gravel overlies the sands of the Magothy (?) fomation, the two aquifers function essentially as one hydrologic unit. The Lloyd sand member of the Raritan formation, the deepest aquifer on Iong Island, is found only in southeastem Brooklyn. It underlies a fairly thick and relatively impermeable clay. Therefore, any flow of ground water from and to the Lloyd sand member would necessarly take place through erosional unconformities, along the contact with bedrock, and through the clay member of the Raritan formation.

Definitions for a few of the basic terms or expressions used in this report are given, as fol1ows:

\section{Coefficient. of storage is the cubic} feet of water discharged from each vertical colum of the adifer with a base 1 ft square as the water level fells 1 ft. For watertable conaltions, the coefficient of storage is equal to the specific yela of the material unwatered during pumping; for antesian conditions, the coefficlent of storage is equal to the water obtained from storage by the compression of a colom of water-bearing material 


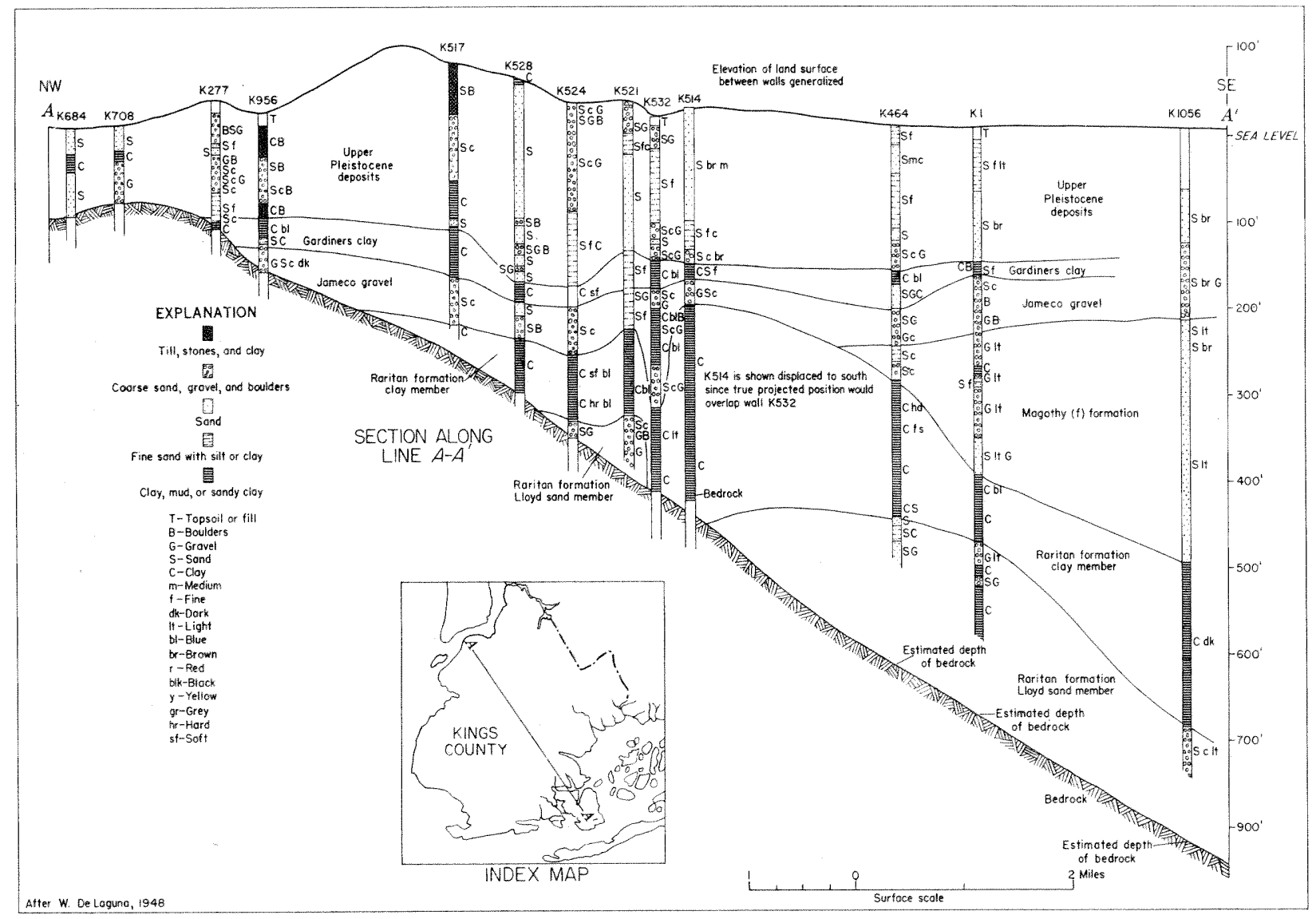

Figure 1.--Geologic section of Kings County, Iong Island, N. Y. 
whose height equals the thickness of the waterbearing material and whose base is 1 ft square.

Coefficient of pemeability in field terms is the rate of flow of water, in gallons a day, that percolates under prevaling conditions through each mile of water-bearing bed under investigation (measured at right angles to the direction of flow) for each foot of thickness of bed and for each foot of hydraulic gradient.

\section{Coefficient of transmissibility is the} product of the field coefficient of permeabiIity and the thickness of the saturated portion of the aquifer.

Cone of depression of a well from which water is being discharged at a given rate is the depression produced in the water table or other piezometric surface by the withdrawal of water. A hydralic gradient is established from a 11 directions towards the well; it increases from zero slope at the point where the water levels are not affected by the pumping to a maximum slope at the pumped we11. After a sufficient shut-down period, the water levels return to the original levels as the water-bearing formation is replenished.

Safe withdrawal is the ret pumping rate at which water can be withdrawn from waterbearing formations without depleting and/or contaminating the supply to such an extent that witharawal at this rate is no longer economically feasible.

\section{PUMPAGE}

Because of the abundance of rainfall and of the widespread occurrence of porous and highly productive water-bearing material, the Eround-water resources of Long Island have been utilized extensively for many years for public water supply, industrial, agricultural, and domestic uses. In Kings County as elsewhere on Long Island, the upper Pleistocene deposits which consist principally of outwash sand, gravel, and till, proved to be the major source of ground water. The Jameco gravel was developed in the county in two different periods, first by the City of New York from about 1904-17 and more intensively by the New York Water Service Corp. from 1927 to 1947. As the sands of the Magothy (?) formation and the Lloyd sand member of the Raritan formation were found only in the southeastem section of Brooklyn, only small amounts of the limited supply of ground water in these two aquifers were removed by a few wells.

The development of ground water in Kings County proceeded at such a fast pace that before World War 1 the rate of witharawal began to exceed the rate of replenishment. The supplies would have been decreased at a faster rete had it not been for the return to the aquifers of small amounts of water pumped for industrial uses, in compliance with the water-conservation law passed by the state in 1933.

The net withdrawal for public supply and industrial uses in Kings County (pl. I) in- creased from 28 med in 1904 to a maximum of 75 mgd in 1929, and decreased to 55 mgd in 1946; pumpage averaged 60 mgd from 1904-47. These quantities include fresh water and undoubtedly some small amounts of diluted sea water, which continued permeating slowly but steadily to the pumped wells after the water levels had been lowered below sea level because of overpumpage.

The net withdrawal for industrial and other uses (excluding public stuply) increased from about $14 \mathrm{mgd}$ in 1904 to about $52 \mathrm{mgd}$ in 1927-28 and stbsequentIy decreased to about $23 \mathrm{mgd}$ in 1947; it averaged about 36 mgd from 1904-47. Such pumpage data for 1904-36, computed by Henderson, were shown by Suter $(1937, p .37)$. Withdrawals for 1937-47 were interpolated by the U. S. Geological Survey from earlier data and those fumished by the New York State Water Power and Control Commission for 1948-50. Actually the gross withdrawals in Brookl m (for all industrial and other norpublic-supply uses) were greater by the amount of water retumed to the aquifers through recharge wells and pits. This form of artificial recharge amounted to about 1 to 2 mgd in the early $1930^{\circ} \mathrm{s}$, was computed to be $7 \mathrm{mgd}$ in 1947, and is increasing every year.

Two major factors contributing to the large decrease in industrial pumpage in Brook$1 \mathrm{yn}$ from 1928-47 were (1) the water conservation law passed by the New York State Legislature in 1933, and (2) the gradual elimination of ice plants. In connection with (1), the State law required that all water used for cooling and similar purposes that was pumped from wells constructed after 1933 whose individual capacity was greater than 100,000 gpd must be retumed to the same aquifer from which the water was taken. Although the law could not be applied to wells already in existence at the time of its passage, it was enforced just as effectively on replacements of the older weIls as on new wells. In connection with (2), as the electric or gas refrigerator gradually replaced the ice box, with which most homes had been equipped previously, the reduction in demand necessitated the shut-dom of meny ice plants. As a result, pumpage by $1 \mathrm{ce}$ plants decreased from $18 \mathrm{mgd}$ in 1936 to $4 \mathrm{mgd}$ in 1947 .

The New York Water Service Corp., the New York City Department of Water Supply, Gas and Electricity, and several small private companies pumpea an average of 23 med for public supply in Brooklyn from 1904-47. During this period, the pumpage was as much as 33 mgd in 1909 and as 1 ittle as 13 mgd $1 \mathrm{n}$. $1918-19$ (pl. I). Before 1916 the New York City Department of Water Supply, Gas and Electricity withdrew relatively large quantities of ground water for public supply at three pumping stations in Brooklyn. However, after 1917 only negligible quantities of water were pumped, in periods of emergency only, by this Department in Kings County. After this date, surfacewater supplies from the reservolx system in upstate New York were available for as stribution. On the other hand, the New York Water Service Corp. Increased its withdrawals from about $4 \mathrm{mgd}$ in 1904 to more than $27 \mathrm{mgd}$ in 1947, to average more than 18 mgd for the Iast 44 " years of its operation in the Flatbush section of Brooklyn. 
Pumpage for public supply was analyzed further to indicate withdrawals by source formetion, as had been done by Thompson and Leggette (1936, po. 20.24) for pumpage from 1904-34. The New York City Department of Water Supply, Gas and Electricity derived as much as $9 \mathrm{mgd}$ (pl. I) from the Jameco gravel and, in addition, small amounts from the Cretaceous aquifers for several years before 1917 . After this date withdrawals in Brooklyn by the city of New York were practically negligible. The New York Water Service Corp. on the other hand began developing artesian. supplies in 1927. The construction of the deeper wells progressed at such a fast pace that by 1933 as many as 16 mgd were being extracted from the artesian aquifers. All these newer wells were screened in the principal beds of the Jameco gravel except one, which was screened in the Inoyd sand member of the Raritan formetion.

After 1933 three additional developments of the deeper aquifers were made but were restricted to locations in the northwestem section of the franchise area of the New York Water semice Corp. at the greatest possible distance from salt water. At the same time the total withdrawals from the artesian formations were reduced gradually from the high rate of $16 \mathrm{mgd}$ to about $7 \mathrm{mgd}$ in 1947. In the meantime, however, the salinity of the artesian waters increased steadily.

During the 44-year period from 1904-47, more than 72 percent of the public water suppiy was obtained by wells screened in the upper Plesstocene (glacial) deposits, about 26 percent by those in the Jameco gravel, and less than 2 percent by those in the Cretaceous sediments. A breakdow of pumpage for industrial and other uses by formation source, would have shown that most of the water was pumped from the shallow water-table aqufers.

Sufficient ground water was removed from the aquifers in Kings County from $1904-47$ to inundate the county having a surface area of about $71 \mathrm{sq}$ mi to a depth of about $63 \mathrm{ft}$, if it were physically possible. Precipitation for the same period totaled about 152 ft. Part of the difference of about 89 ft was lost to the sea by underground outflow in the early years and by sewer outflow during the late years. The remainder was consumed by evapotranspiration.

\section{SAIT-WATER INTRUSION}

As a result of continuous pumping in excess of the safe withdrawal, ground-water levels in Kings County were gradually lowered below sea level in all but the extreme southem section of the county. This situation led to salt-water encroachment, as about 70 percent of Brooklyn is surrounded by sea water having a chloride content ranging from 10,000 to 20,000 pm. Sea water entered the shallow and artesian water-bearing formations in Kings County by induced infiltration from all directions except the northeast and parts of the southwest. SIowly, but more or less steadily, it moved landward downgradient toward the apex of the cone of depression in northwestern Brooklyn. Because of this in- trusion, the chloride content began to increase first in coastal welis and later in wells at greater distances from the shore Iine.

The rate of increase of salinity at any one locality varied with many factors: (1) rate of overpumping, (2) rate of presh-water replenishment, natural or artificial, (3) coefficient of transmissibility and coefficient of storage (or specifle yield) of the aquifer, (4) distance from the source of contamination, and (5) ability of the sands, gravels, and clays composing the water-bearing zones to rem move or reauce chemicaliy or perhaps to absorb or absorb some sma.11 percentage of the chloride ions of the encroaching sea water.

Water pumped for public supply was sampled at frequent and regular intervals by the New York Water Service Comp duming the many years of its operation in central Brooklyn. Water samples were taken from in dustrial wells only occasionally before the middle $1930^{\prime} \mathrm{S}$ after which time the U. S. Geological Survey began a gradually expanding systematic program of sampling at many selected industrial wells in Brooklyn and particular Iy in the northwestexn section of the county. The first map on record depicting isochlors and chloride content of water in Brooklm was prepared by Wiggin, Sarborr, and Brush ( 1933 exhibit $J$ ). Their study showed that in 1932 the chloride content was already high at some weIls in the upper Pleistocene deposits near the shore ine of the county. They pound that the artesian water in this local1ty was even more highly contaminated by salt water than was the unconfined water. However, in the central thira of Kings County at the greatest distances from sea wator, the salinity in the water-table and artesian aquifers was shown by them to be less than 40 prm in general and not more than 80 ppm in 1932.

Because withdrawals in Brooklyn were in excess of replenishment for years, the chIoride content of water pumped from the upper. Pleistocene deposits within a mile or two of the shore line in the northwestern and southeastern sections of Kings County increased very rapidly during the 15 - yr pertod ended in 1947. Concentrations ranging from 1,000 to 8,000 ppm were indicated at many coastal wells in 1947. At many others, the salinity was less than 1,000 pom but more than 100 ppm. The quantity of salt water induced along the upper Pleistocene deposits as far landward as central Brooklon was apparently small, be cause in this locality by 1947 the chloride content of ground water was low. Esther the contamination was slight, or recharge from precipitation provided a sufficient compensating effect. Records on the quality of the shallow ground water indicate that the rate of increase in salinity in the upper pleistocene deposits varied to a certain extent with the changing average rates of precipitation, from month to month, season to season, and year to year.

At all times since 1932, water pumped from wells screened in the Jameco gravel was in general much more contaminated by salt water than the water removed from the upper Pleistocene deposits. The intrusion into this artestar acuifer wes faster and also 
farther landward. Such action is explainable because the coefficient of storage, an important hydraulic characteristic of an artesian formation, is much smaller than the specific yield of the overlying water-table formations in Brooklyn.

The chioride content of water pumped by the New York Water Service Corp. from the water-table and artesian aquifers for public supply is listed by years in table 1 , for the period $1927-47$.

Although more than 72 percent of the total withdrawals for public supply were from the shallow aquifers, the chloride count increased rather slowly in these formations. The salinity had not reached $200 \mathrm{ppm}$ in any of the water-table wells and was much less at many of them by 1940. Recharge from precipitation, a large coefficient of transmissibility, and a relatively large storage capacity of the aquifer effectively prevented large increases. After 1940 , as the withdrawals from the upper Plesstocene deposits were Increased because of the demand and the higher percentage of chloride in the artesian formations, the chloride content in these water-table wells increased more rapidiy. By 1947 it was as much as $710 \mathrm{ppm}$ ( $f i g .2$ ) at one of the older wells (in use before and after 1920) in the southern half of the franchise area of the New York Water Service corp. In the northern half, the salinity at several wells constructed after 1940 increased slightly but was less than $100 \mathrm{ppm}$ in June 1947 .

Pumping from the deeper artestan wells, started in 1927 by the New York Water Service Corp., had increased rapidly to $16 \mathrm{mgd}$ in 1933. As a result, the salinity of the water in the artesian wells in the southern section of the franchise area of the New York Water Service Corp. began to increase very rapidly. It rose to more then $100 \mathrm{ppm}$ at wells K52I, K523, and K525 (index map, fig. 8) after they had been pumped less than 5 yr. As soon as this was recognized, pumping from the deeper wells was reduced and recharging the deeper wells from the shallow formations was tried at various times. These practices retarded the intrusion only slightly. Although wells K523 and K525 were used only in times of emergency, and there was a gradual reduction of pumping in the other artesian wells, the contamination continued to increase each year: by 1947 it had spread to practically all sections of the franchise area of the New York Water Service Corp. This spread of contamination was due primarily to the fact that the artesian formations developed for ground water have a low storage capacity, and the natural recharge of fresh water per. colating from the overlying and underlying aquifers continued to be less than the withdrawals. Recharging some of the deeper wells with water from the shallow formations also proved to have only a temporary and more or less local effect in reducing the salinity. This recharging was done perhaps as much to utilize more efficiently the limited supply of ground water as to reduce the salinity of the artesian water.
In 1947, all except two of the New York Water Service Corp. wells screened in the Jameco gravel yielded water having a chloride content greater than $260 \mathrm{ppm}$ and as high as 830 pom (fig. 2). The salinity of water in two weIIs, K517 and K526, in the extreme northwestem comer of the franchise area (approximately in the geographical center of Brooklyn) was less than 100 ppm. At well K520 in the extreme northeastem comer of the franchise area, the chloride content had increased by January 1946 to $1,550 \mathrm{ppm}$. This content represents the highest for any well sampled by the New York Water Service Corp. in the Flatbush section of Brooklyn.

When the pumping in Flatbush was shut down in June 1947, the water levels recovered ranidy (tables 2 and 3 and fig. 5). Hovever, brackish water continued to move, at a decreased rate, in a landward direction toward the bottom of the cone of depression in the northern section of Brooklyn, where the water table in December 1950 was still below sea Ieve1. The direction of flow was reversed only in the southern and southeastem areas (fig. 4), where the water levels by December 1950 returned to altitudes above sea level.

As the New York Water Service Corp. wells in the Jameco gravel in the southem half of Brooklyn were abandoned in June 1947, the trend of the chloride content in the Jameco gravel could not be ascertained at these wells after their shut-down. One of the wells, K522, was pumped by an industrial firm during the recent "water shortage" in New York City. Water sampled for chloride content at this well shows a somewhat lower salinity than that before the shut-down. Data avajIable for wells in the Jameco gravel in northwestern Brooklyn show, in general, a diminished rate of increase in salinity.

Contamination of ground water by sea water is usually a rather slow process and in Brooklyn it took place and increased during many years of overpumping. The opposite trend, the freshening of ground water will recuire approximately a corresponding number of years. No large change in the salinity was noted $3 \frac{1}{2}$ yr after the shut-down of pumping from the shallow formations. In fact, the beneficial effect is expressed, in general, only in a decrease of the rate of increase in salinity of ground water.

\section{TREND OF THE WATER TABLE AND ARTESIAN LEVELS FROM 1903 TO 1947}

The trend of groundwater levels in Brooklyn is an expression of changes in storage in the underground aquifers. Changes in storage result from differences between recharge and discharge. In this area groundwater recharge is derived from (I) direct precipitation, (2) underflow from beyond the county, (3) water retumed a rificially through wells, and (4) inflow of sea water. Discharge is by means of (I) witharawals by wells, (2) evapotranspiration, (3) sewer outflow, (4) stream runoff, and (5) underflow to sea." When recharge exceeds discharge during 


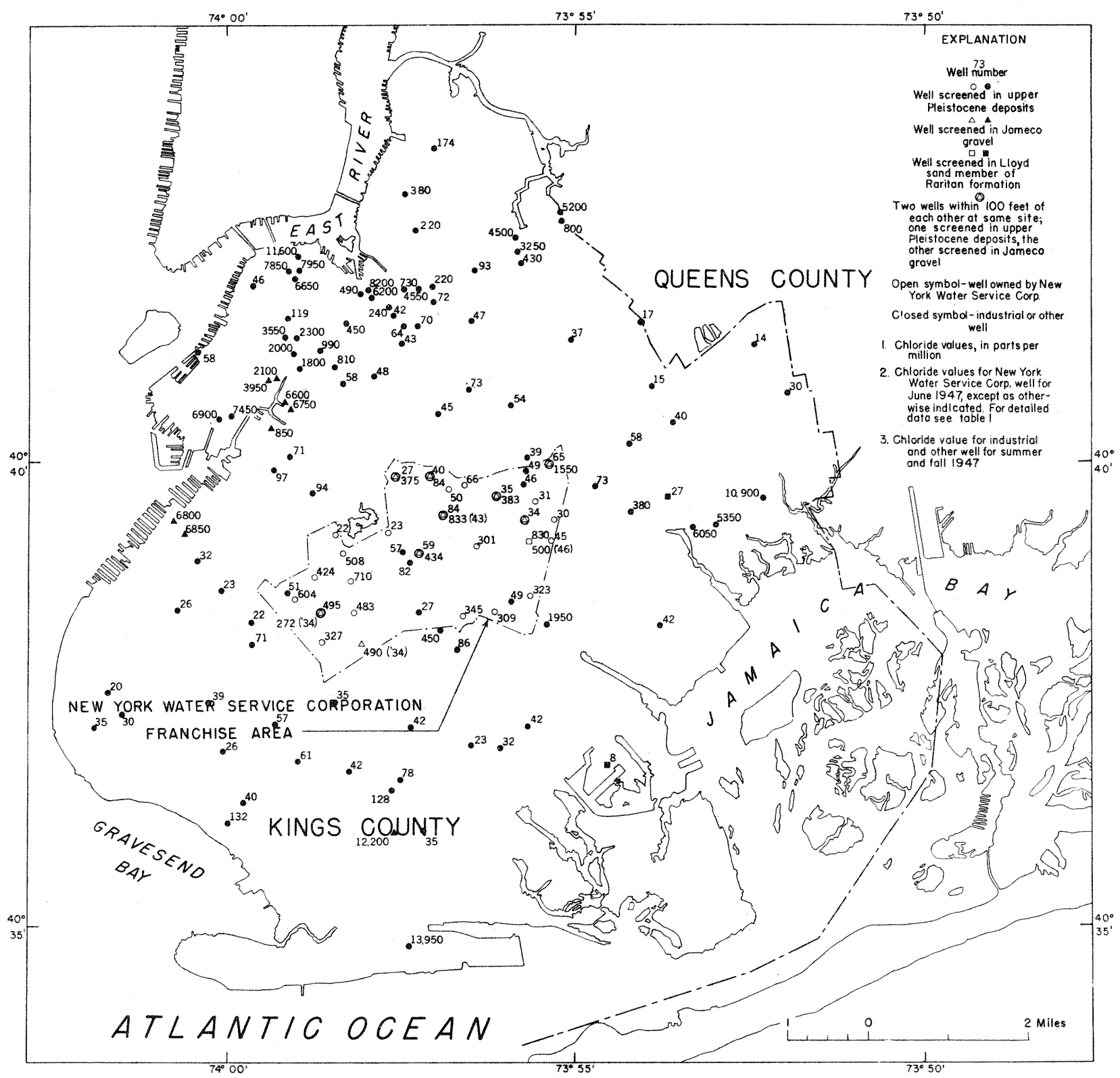

Figure 2.--Chloride content of ground water in the New York Water Service Corp. wells in Kings County, N. Y. 
Table 1.-Chloride content, in parts per million, of water pumped by the New York Water Service Corp. in Kings County, N. X., 1927-47

Cata furnished by Mount Prospect Lahoratory, City of New York Water Service Corp. For data on location of wells see

\begin{tabular}{|c|c|c|c|c|c|c|c|c|c|c|c|c|c|c|c|c|c|c|c|c|c|}
\hline $\begin{array}{l}\text { WeId } \\
\text { no. }\end{array}$ & 1927 & 1928 & 1929 & 1930 & 1931 & 1932 & 1933 & 1934 & 1935 & 1936 & 1937 & 1938 & 1939 & 1940 & 1941 & 1942 & 1943 & 1944 & 1945 & 81946 & b1947 \\
\hline \multicolumn{22}{|c|}{ Welis screened i } \\
\hline $\mathrm{K} 50 \mathrm{I}$ & 18 & 22 & 23 & 20 & 21 & 19 & 32 & 40 & 72 & $\cdots$ & 72 & 224 & 61 & & $\cdots$ & 146 & 603 & 793 & 436 & 758 & $c 495$ \\
\hline 45503 & 25 & 21 & 22 & 21 & 22 & 22 & 28 & 28 & 30 & 28 & 25 & 39 & 150 & 145 & $\ldots$ & .. & 513 & 700 & 360 & 548 & 424 \\
\hline K504 & $\ldots$ & & $\ldots$ & $\ldots$ & & 22 & 104 & 146 & 60 & 31 & 33 & 50 & 53 & 72 & 87 & 94 & 107 & 102 & 207 & 281 & 309 \\
\hline K503 & ï & $\ddot{i s}$ & $\ddot{2 i}$ & $\ddot{2} 20$ & 30 & 27 & 35 & 30 & 28 & 26 & 25 & 28 & 26 & 27 & 29 & 27 & 27 & 34 & 31 & 33 & 34 \\
\hline K507 & 24 & $\ldots$ & 44 & 39 & 38 & 35 & 37 & 37 & 35 & 40 & 40 & 45 & 46 & 46 & 47 & 45 & 40 & 39 & 38 & 35 & 35 \\
\hline K508 & 27 & 31 & 33 & 28 & 29 & 31 & 31 & 31 & 30 & 28 & 28 & 27 & 25 & 24 & 49 & 266 & 544 & 561 & 265 & 505 & 508 \\
\hline K51d & 24 & 27 & 28 & 25 & 27 & 25 & 27 & 25 & 27 & 24 & 25 & 28 & 56 & 128 & 229 & 307 & 366 & 370 & 497 & 707 & 624 \\
\hline$K 012$ & 20 & 23 & 24 & 21 & 24 & 22 & 25 & 26 & 27 & 26 & 28 & 28 & 33 & 129 & 235 & 274 & 510 & 464 & 451 & 461 & 710 \\
\hline K5 53 & 22 & 23 & 24 & 23 & 43 & 183 & 73 & 90 & 112 & 84 & 93 & 91 & 139 & 177 & 228 & 250 & 325 & 820 & 418 & 895 & 327 \\
\hline K514 & 13 & 12 & 25 & 42 & 48 & 65 & 47 & 154 & $\ldots$ & 51 & 74 & 69 & 103 & 110 & 217 & 247 & 303 & 194 & 384 & 665 & 323 \\
\hline K516 & 21 & 21 & 28 & 28 & 33 & 34 & 35 & 39 & 42 & 45 & 45 & 48 & 46 & 48 & 52 & 50 & 52 & 56 & 60 & 64 & 65 \\
\hline K527 & $\ldots$ & $\cdots$ & $\ldots$ & $\ldots$ & $\ldots$ & $\ldots$ & $\ldots$ & 59 & 58 & 53 & 49 & 48 & 46 & 43 & 44 & 41 & $4 I$ & 40 & 47 & 49 & 59 \\
\hline dK529 & $\ldots$ & $\ldots$ & $\ldots$ & ... & . & $\ldots$ & $\ldots$ & 29 & 25 & 23 & 23 & 23 & 90 & 144 & 251 & 340 & 445 & $\therefore$ & $\ldots$ & $\ldots$ & $\ldots$ \\
\hline$\frac{\mathrm{K} 530}{\mathrm{~K} 1232}$ & $\cdots$ & $\cdots$ & $\ldots$ & $\cdots:$ & $\cdots$ & $\cdots$ & $\cdots$ & $\cdots$ & $\cdots$ & 33 & 31 & 77 & 146 & 288 & 360 & 180 & 283 & 699 & 268 & 152 & 483 \\
\hline $\begin{array}{l}\mathrm{K} 2233 \\
\mathrm{~K} 1234\end{array}$ & $\cdots$ & $\cdots$ & $\cdots$ & $\ldots$ & $\cdots$ & $\cdots$ & $\cdots$ & $\cdots$ & $\cdots$ & $\cdots$ & $\cdots$ & $\cdots$ & $\cdots$ & $\cdots:$ & $\cdots$ & 17 & 23 & 34 & 30 & 32 & 33 \\
\hline $\mathrm{K} 1329$ & $\cdots$ & $\cdots$ & $\cdots$ & $\cdots$ & $\ldots$ & $\cdots$ & $\ldots$ & $\cdots$ & $\cdots$ & $\cdots$ & $\cdots$ & $\ldots$ & $\cdots$ & $\cdots$ & $\ldots$ & 59 & 52 & 48 & 48 & 48 & 50 \\
\hline$K \perp 331$ & $\cdots$ & $\cdots$ & $\ldots$ & $\cdots$ & . : & $\cdots$ & $\cdots$ & $\ldots$ & $\cdots$ & $\ldots$ & . & $\cdots$ & $\cdots$ & $\ldots$ & $\cdots$ & $\ldots$ & 72 & 166 & 66 & 65 & 66 \\
\hline $\mathrm{K} 338$ & $\cdots$ & $\ldots$ & .. & $\ldots$ & $\cdots$ & $\cdots$ & $\cdots$ & $\ldots$ & $\cdots$ & $\ldots$ & $\ldots$ & $\cdots$ & $\cdots$ & $\cdots$ & $\cdots$ & $\ldots$ & 22 & 24 & 23 & 25 & 27 \\
\hline KI343 & $\ldots$ & $\cdots$ & $\cdots$ & $\ldots$ & $\ldots$ & $\therefore$ & ... & $\cdots$ & $\cdots$ & $\cdots$ & $\cdots$ & $\ldots$ & $\ldots$ & $\cdots$ & $\cdots$ & $\cdots$ & 21 & 24 & 26 & 29 & 31 \\
\hline KI351 & $\ldots$ & $\ldots$ & $\ldots$ & $\cdots$ & $\ldots$ & $\cdots$ & $\ldots$ & $\ldots$ & $\ldots$ & $\cdots$ & $\cdots$ & $\ldots$ & $\cdots$ & $\cdots$ & $\cdots$ & $\cdots$ & $\ldots$ & 43 & 67 & 76 & 84 \\
\hline K1357 & $\ldots$ & $\cdots$ & $\cdots$ & . & $\cdots$ & ... & .. & $\ldots$ & . & $\ldots$ & $\ldots$ & $\ldots$ & $\ldots$ & $\cdots$ & $\cdots$ & $\cdots$ & $\cdots$ & 30 & 22 & 22 & 22 \\
\hline K1359 & $\ldots$ & $\ldots$ & $\therefore$ & $\ldots$ & $\ldots$ & $\ldots$ & $\ldots$ & .. & $\ldots$ & $\ldots$ & $\ldots$ & $\cdots$ & $\ldots$ & $\ldots$ & $\ldots$ & $\ldots$ & $\ldots$ & 45 & 42 & 43 & 46 \\
\hline$K 1360$ & $\ldots$ & $\cdots$ & $\ldots$ & $\ldots$ & $\cdots$ & $\cdots$ & $\ldots$ & $\cdots$ & $\ldots$ & $\cdots$ & $\cdots$ & $\cdots$ & $\ldots$ & ... & $\ldots$ & ... & $\cdots$ & 59 & 171 & 263 & 301 \\
\hline KI 363 & $\ldots$ & $\ldots$ & $\cdots$ & ... & . & $\ldots$ & $\ldots$ & $\ldots$ & $\ldots$ & $\cdots$ & $\cdots$ & $\ldots$ & . & $\ldots$ & $\ldots$ & $\ldots$ & $\ldots$ & $\ldots$ & 26 & 28 & 30 \\
\hline KI 516 & . & $\ldots$ & $\ldots$ & . & $\ldots$ & $\ldots$ & $\ldots$ & $\ldots$ & $\cdots$ & $\ldots$ & $\ldots$ & $\ldots$ & $\ldots$ & $\cdots$ & $\cdots$ & $\ldots$ & $\ldots$ & $\cdots$ & $\cdots$ & 35 & 40 \\
\hline eKI517 & $\ldots$ & $\ldots$ & $\ldots$ & ... & $\ldots$ & $\ldots$ & $\cdots$ & $\ldots$ & $\cdots$ & $\ldots$ & $\cdots$ & $\ldots$ & $\ldots$ & $\cdots$ & $\ldots$ & $\cdots$ & $\cdots$ & $\cdots$ & $\cdots$ & 345 & $\ldots$ \\
\hline
\end{tabular}

Wells screened in the Jameco gravel (artesian wells)

\begin{tabular}{|c|c|c|c|c|c|c|c|c|c|c|c|c|c|c|c|c|c|c|c|c|c|}
\hline K517 & 4.2 & 4.2 & 4.3 & 5 & 4.8 & 5 & 7.9 & 11 & 13 & 14 & 13 & $\begin{array}{l}12 \\
99\end{array}$ & $\begin{array}{r}12 \\
173\end{array}$ & $\begin{array}{r}16 \\
130\end{array}$ & $\begin{array}{r}22 \\
150\end{array}$ & $\begin{array}{r}24 \\
83\end{array}$ & $\begin{array}{r}33 \\
203\end{array}$ & $\begin{array}{r}42 \\
225\end{array}$ & $\begin{array}{r}53 \\
285\end{array}$ & $\begin{array}{r}63 \\
369\end{array}$ & $\begin{array}{r}84 \\
383\end{array}$ \\
\hline $\begin{array}{l}1520 \\
K 52\end{array}$ & $\cdots$ & $\because$ & $15^{\circ}$ & 19 & $\begin{array}{l}11 \\
19\end{array}$ & $\begin{array}{l}10 \\
15\end{array}$ & $\begin{array}{l}27 \\
25\end{array}$ & 24 & 27 & 31 & 41 & $\ldots$ & 62 & 101 & 161 & 263 & 448 & 696 & 1410 & 1550 & $\ldots$ \\
\hline K52: & $\therefore$ & $\therefore$ & $\ldots$ & 20 & 28 & 27 & 30 & 24 & 21 & 22 & 27 & 50 & 110 & 170 & 280 & 348 & 386 & 445 & 432 & 451 & 434 \\
\hline $\begin{array}{l}\text { KEE } \\
\text { K52 }\end{array}$ & $\therefore$ & $\cdots$ & $\therefore$ & $\begin{array}{l}22 \\
\ldots\end{array}$ & $\begin{array}{l}23 \\
68\end{array}$ & $\begin{array}{l}26 \\
75\end{array}$ & $\begin{array}{r}120 \\
68\end{array}$ & $\begin{array}{r}490 \\
52\end{array}$ & $\begin{array}{l}44 \\
61\end{array}$ & $\begin{array}{l}60 \\
74\end{array}$ & $\ddot{7} \dot{9}$ & $\ddot{9}$ & i் & $\ddot{i} \dot{2}$ & iijo & $\ddot{1} \dot{8} \circ$ & $\ddot{2} \ddot{2}$ & $\ddot{2} \ddot{7} \dot{2}$ & $\ddot{4} \dot{2} \dot{8}$ & $\dot{6} \dot{0} \dot{0}$ & $\ddot{8} \ddot{3}$ \\
\hline $\mathrm{K} 225$ & $\ldots$ & $\ldots$ & $\therefore$ & $\therefore$ & 47 & 130 & 198 & 272 & f.44 & 0119 & $f 91$ & $\ldots$ & $\ldots$ & $\ldots$ & $\cdots$ & ... & $\ldots$ & $\ldots$ & $\ldots$ & $\ldots$ & $\cdots$ \\
\hline $8 K 52$ & $\ldots$ & ... & $\cdots$ & $\ldots$ & 9.0 & 12 & 14 & 16 & 19 & 20 & $\therefore$ & 25 & 22 & 23 & 33 & 55 & $\ddot{\ddot{O}}$ & 39 & 45 & 50 & 65 \\
\hline $\mathrm{K} 52 \mathrm{Z}$ & $\cdots$ & $\cdots$ & $\cdots$ & $\cdots$ & $\cdots$ & $\cdots$ & $\cdots$ & 40 & 31 & 29 & 34 & $\begin{array}{l}38 \\
23\end{array}$ & 43 & GI & $\begin{array}{l}94 \\
34\end{array}$ & 278 & 833 & $\ldots$ & $\ddot{2} \dot{50}$ & $\ddot{3} 4 \hat{0}$ & 375 \\
\hline $\mathrm{K} 528$ & $\cdots$ & $\cdots$ & $\cdots$ & $\cdots$ & $\cdots$ & $\cdots$ & $\cdots$ & $\cdots$ & $\cdots$ & $\cdots$ & $\therefore$ & 0 & $\ldots$ & $\ldots$ & $\ldots$ & 54 & 84 & 140 & 194 & 245 & 263 \\
\hline
\end{tabular}

Well screened in the liloyd sand member of the Raritan formation (artesian well)

\begin{tabular}{|c|c|c|c|c|c|c|c|c|c|c|c|c|c|c|c|c|c|c|c|c|c|}
\hline K521 & $\ldots$ & $\ldots$ & 29 & 16 & 68 & $1 \leqslant 3$ & 260 & 262 & $\mathrm{f} 46$ & f43 & f45 & 1213 & $f 173$ & 402 & 500 & 519 & 420 & 517 & 525 & 500 & $\ldots$ \\
\hline
\end{tabular}

a Records for 1927-46 represent year-end data except that in 1946 for well K52l the chloride content for January 1 s listed,

b For 1947, records for June are listed.

c Underlined numbers are shown in figure

d Wells K503 and K529 are at same

e Well Kl5l7 is near well Kl479.

\& Welis K526 and K531 are at same site. 
a given period, storage increases and water levels rise. Conversely when discharge exceeds recharge, storage decreases and water levels decline. Thus water-level records are important indicators in maintaining an inven tory of ground-water supplies.

In the Brooklyn area the natural regimen of ground water has been strongly affected by (1) the construction of bullaings and streets which effectively prevent recharge from direct precipitation over a large part of the area, and (2) heavy withdrawals of ground water by pumping from wells. The effects of these factors are strongly indicated by records of water levels that have been obtained since 1903.

Of the many causes set forth above, precipitation, pumping, and sewer monof played the principal roles in the conditioning of events responsible for the major changes of water levels in Brooklyn.

The water table in 1903 was above sea level in the entire borough of Brooklyn and near the queers County Iine was as high as $20 \mathrm{ft}$ above sea level. This is clearly indicated by the contour map for 1903 crepared by Wiggin with the cooperation of Brush and Sanborn (1933, exhibit A) for the hearings in connection with the application before the New Vork State Water Power and Control Commission by the olty of New York for the development of additiona 1 ground-water supplies in westem Long Is land. Their 1903 contour map has been reproduced in plate 2 ; it includes contours for Queens County as mapped by Spear. Burr, and others (1904).

Leggette $(1940$, pp. 529-552), Jacob (1945) and other investigators concluded from detailed studies of precipitation records that ground-water Levels in Long Island for several years before and after the turn of the last century had been record hith since the early $1800^{\prime}$ s. The very high precipttation rate for many years before the beginning of the twentieth century and the inconsequential withdrawals of ground water during the earlier vears allowed the water table to continue rising gradually and persistently to the extremely high levels observed in 1903.

During the next 30 yr period ended in 1933, the water table declined rapialy to dangerous ly low levels in Brooklyn. The primary contributory factors were the reduction of natural recharge (to the underlying aquifers) caused by the works of man-sewers, bullings, streets, sidewalks, pavements-and the continued heavy withdrawal in excess of replenishment. The building improvement: were necessitated by the rapid increase of population in Kings County and the industrialization and commercialization of the northwestern section. To make matters worse, the precipitation was below nomal during most of these years, especialiy during the early $1930^{\circ} \mathrm{s}$, and, as a result, the decilne of water levels was acclerated.

By 1933 a huge craterlike depression of the water table had developed. The water table declined to stages below sea level in most of Brooklyn and was more than $15 \mathrm{ft}$ below sea level in the northwestem section. Such tremendous, and for the most part un suspected, changes for the worse were reported in a contour map for 1932 prepared cooperam tively by Wiggin, Brush, and Sanbom (1933, exhibit A). This map has been reproduced in plate 2. The rather extreme low levels to which the water table had receded was a revelation to many engineers, some of whom were previously of the opinion that no radical change in the position of the water table had taken place in Kings County since 1903, and that adational large ground-water developm ments in Erooklyn were still posilibe.

As soon as the seriousness of the situaton in western Long Island was fully comprem hended, the New York State Legislature passed on April 28, 1933, section 52 la of the water conservation law, to protect the public water supply on Long I'sland from further overdevelopment. This law empowered the New York State Water Power and Control Commission to act on al1 new applications for additional water supply on Lons Island for all wells having a capacity greater than 100,000 gpa, and required that 211 water pumped for cooling and similar purposes be returned to the aquifer from which it was taken. The Commission was not given any jurisdiction over we 11 s already in place and in use, or of any agricultural wells constructed for agricultural uses.

One of the first technical contributions by the New York State Water Power and Conm trol Commssion, which resulted from the water conservation law passed in 1933, was a more detalled map deplcting water-table contours in 1936 for all of Long Island. This map prepared under the supervision and direction of Suter (1937, opposite p. 49) was based on more field data than the 1933 map. The westem section of Suteris map duplicated ir plate 2 shows that the reserves in the water-bearing fometions in Kings County were more depleted than frst suspected in 1933 . Water levels as low as 35 ft below sea level were reported for 1936 in northwestem Brooklyn.

A few years later, Jacob $(1945$ a) pre. pared the water-table map for westem and central Long Island. N. Y. for May 1943. He indicated levels as low as $25 \mathrm{ft}$ below sea level in Brooklyn and was aware that lower levels existed locally at and near pumped wells in the "crater area" (01. 2). From May 1943 to the time of the general shut-down of pumping In Flatbush in June 1947, only small changes in water level were observed in Brooklyn. It was thus considered that con$\frac{\text { tours of water levels on the map of } 1943}{\text { approximated in genera the the position of the }}$ water table in June 1947 .

The trend of water levels in Kings County from 1903-47 can be summarized as follows: Because of overpumping, works of man, and below normal precipitation, the water table declined very rapidiy from a position several feet abore sea level in 1903 to many feet below sea level in 1933. The decline persisted through 1940, and water levels more than 25 ft below sea level were general in sections 
of northwestem Brooklyn. After 1941 slight recoveries were indicated at some wells; at most of the others the levels dropped very Iittle. The declaration of the downward trend in most localities, and its reversal at some we11s, were attributable to the gradual reduction of pumping, to the above-nomal precipitation, and to artificial recharge. In general, in more than 75 percent of Kings County water levels remanned below sea level for more than $30 \mathrm{yr}$.

Comparatively Iittle is known about the plezometric levels in the Jameco gravel, an artesian aquifer, and much less about levels in the deeper artesian fomations in Brooklyn, for the period 1903-33. Fowever, it can be assumed that the piezometric surface in the Jameco gravel was above sea level in 1903 . and perhaps at approximately the same altitude as the water table. It may also be assumed that, as the Jameco gravel was pumped for only a few years during the period 1903-26, plezometric levels were higher than the water table during most of this period. After 1926 the artesian levels declined very rapidly because excessive withdrawals were made from the Jameco gravel by the New York Water Service Corp. for public water supply in Flatbush and by industrial concerns in sections of northwestern Brooklyn.

The levels in 1933 and the trend of levels between $1933-47$ are suggested by a few nearly continuous records for a relatively small number of artesian wells in Brooklyn. However, the avaliable data are incomplete and too few to allow an accurate plotting of an isopiestic map for any date. It appears more likely than not, that from 1933-47, the water table in the upper pleistocene deposits and the piezometric surface for the Jameco gravel were at approximately the same altitude. There certainly is less doubt about this being true in 1947, especially in the Flatbush secm tion of Brooklyn, as is evidenced by waterlevel records obtained just before and after the general shut-down of pumping in June 1947 .

\section{RECOVERY OF WATER LEVELS FROM JUNE 1947 TO DECEMBER 1950}

\section{Water-Table Deposits}

The water table in Kings County, as measured at many observation wells shown in figure 5 and listed in tables 2 and 3, recovered rapidly from June 1947 to December 1950 , as a result of the complete cessation of pumping in central Brooklyn. For about $1 \frac{1}{2}$ yr before the shutdow in June 1947, the New York Water Service Corp. pumped at an average rate of about 21 mgd from about 26 wells screened in the upper Plelstocene (waterm table) deposits within its franchise area.
By December 1950, ground-water levels rose (fig. 4) from below sea level to above sea level in more than the entire southern half of Kings county; and in the southwestem section, levels as high as 4 ft above sea level were measured. In northem BrookI yn also, where the water table had receded previously to levels as much as 35 ft below sea level, aporeciable improvement of water levels in the ground-water conditions were noted after the shut-dow; in this section of the county, the recovery ranged from 1 ft to as much as $11 \mathrm{ft}$. In general, the amount of rise decreased with an increase in distance from the previously pumped wells (fig. 5) and ranged from more thar 19 ft in central Brooklyn to about I ft near the perimeter of Kings County. The net gain in storage in the water-table formations in Brooklyn was about 20 bilion gallons from June 1947 to December 1950.

The recovery in the western section of Queens County, being sma11, overshadowed by the greater effect of the ever-increasing pumping by private companies furnishing pubIf supply and also by industrial concerns. An increase in pumping and the precipitation trend caused a net drop in levels in westem Queens County from June 1947 to December 1950.

Recoveries at several intervals after the shut-down are illustrated by the profiles of the water table at three cross sections (fig. 6) shown on the index map (fig. 3). Levels measured on June 30,1947 , during the first day of the shut-down lafter the pumps were shut off), constitute the basis of recovery. Profiles for 1947-50 are compared to those for 1903 which were drawn from Wiggin's contour map (1933, exhibit A). In spite of the relatively large recovery of water levels in Brooklyn in $3 \frac{1}{2}$ yr, the water table in December 1950 was still many feet below that reported for 1903 , at which time the water table in Brooklyn had been above sea level everywere and as high as $20 \mathrm{ft}$ above near the Queens County line.

The trend of water levels in Kings County differed radically from that in other parts of Iong. Island before as well as after the shut-down of pumping by the New York Water Service Corp. In Brookiyn, the pumpage pattem is reflected much more prominently than variations in precipitation. Elsewhere on Long Island, the opposite is generally true. Monthit hydrographs from $1932-50$ for four wells in Kings County ( $11 \mathrm{~g} .7)$ contrast strikingly with that expressing the average level of 14 selected wells in Nassau and Suffolk counties and illustrate effectively the point under discussion.

of the chosen wells in Kings County, records at weII KI264 reflect conditions in 


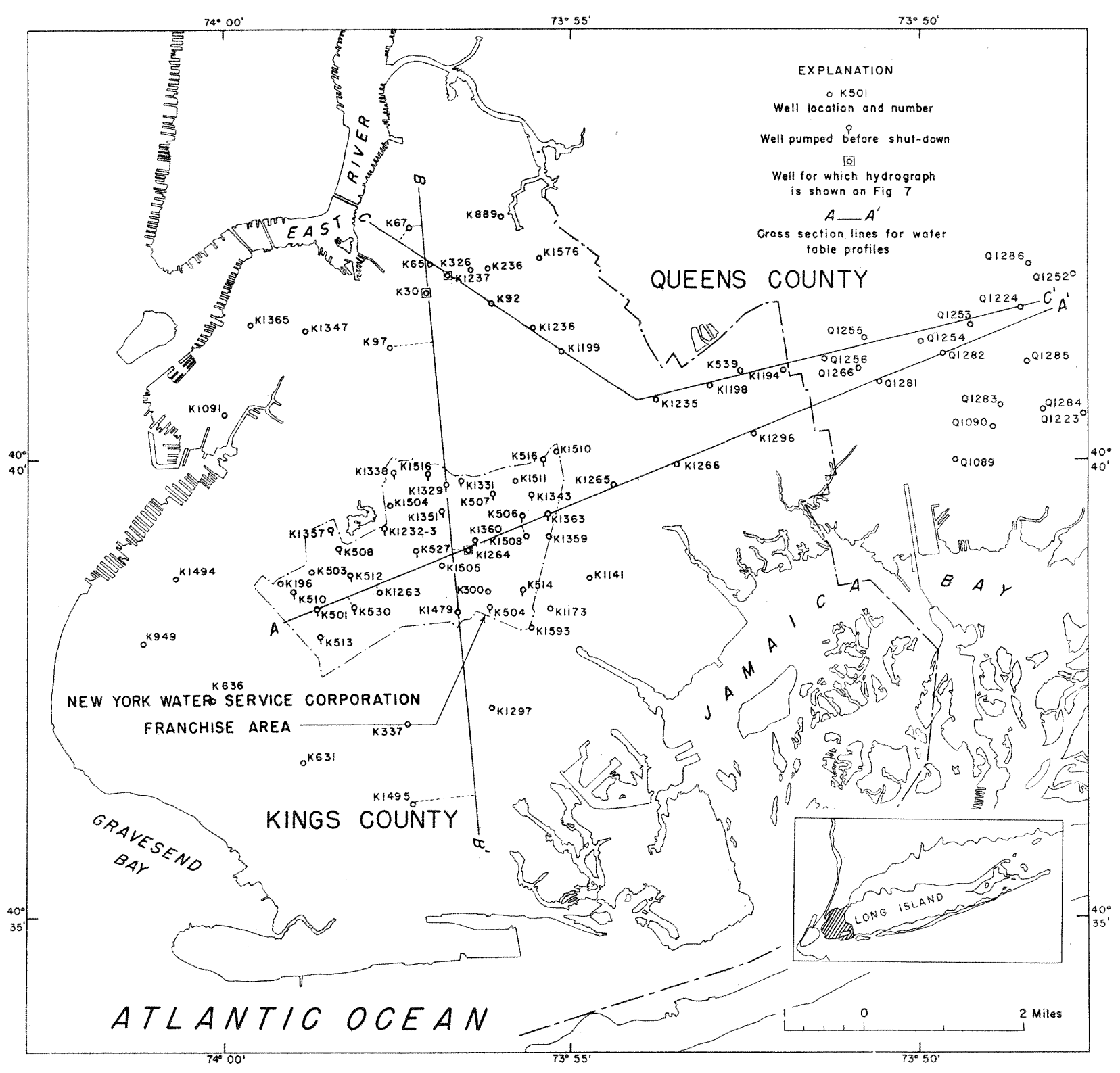

Figure 3.--Index map showing water-table wells and cross-section lines in Kings and Queens Counties, N. Y. 


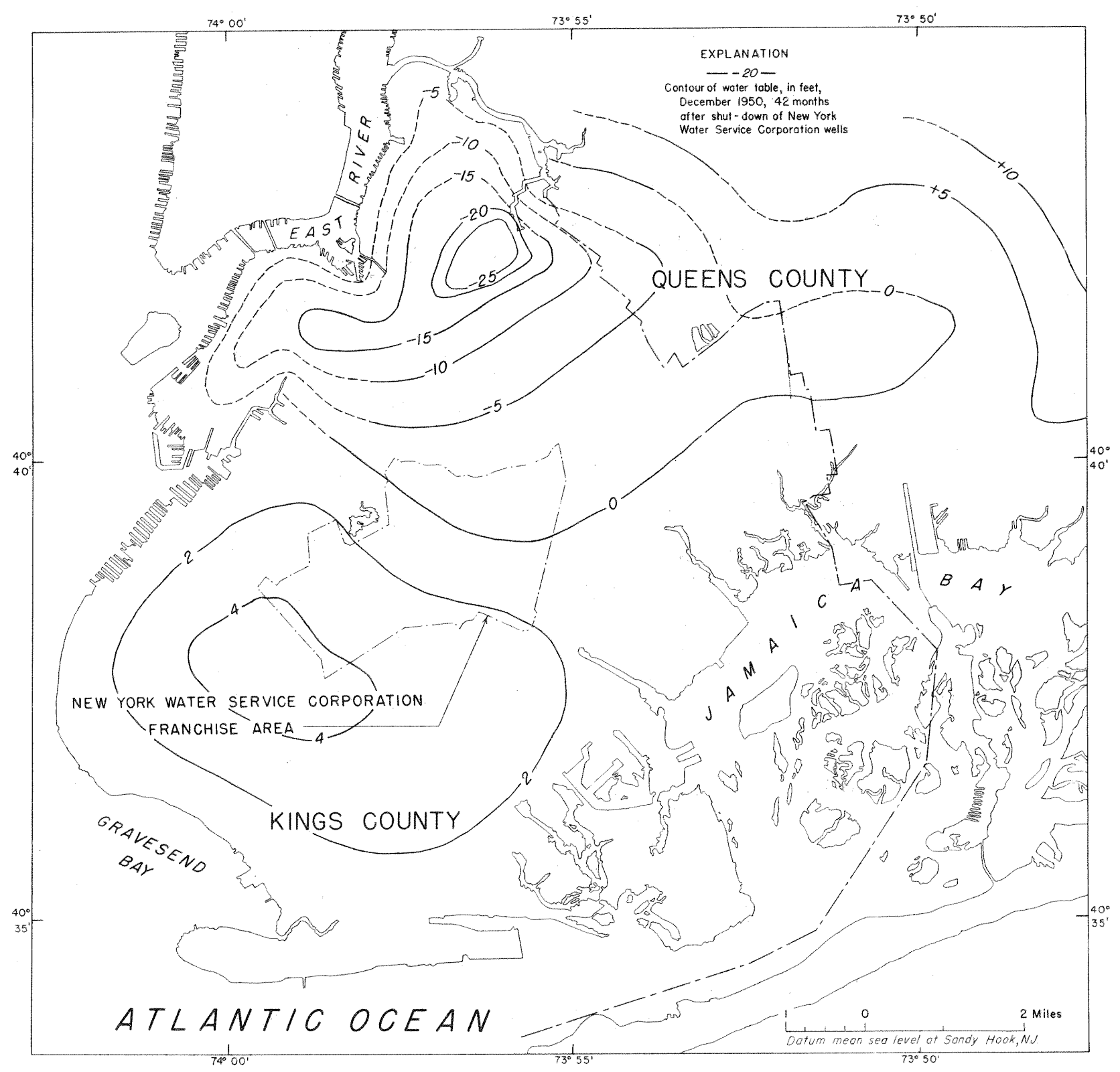

Figure 4.--Position of water table in Kings and Queens Counties, N. $Y_{*}$, in December 1950. 
Table 2.-Ground-water levels, in feet, mean-sea-level catum, in wells in Kings and Gueens Counties, N. Y., from June 1947 to December 1850

[Status of well: NR, well idle before shut-down, June 1947; P, well pumped before shut-dow]

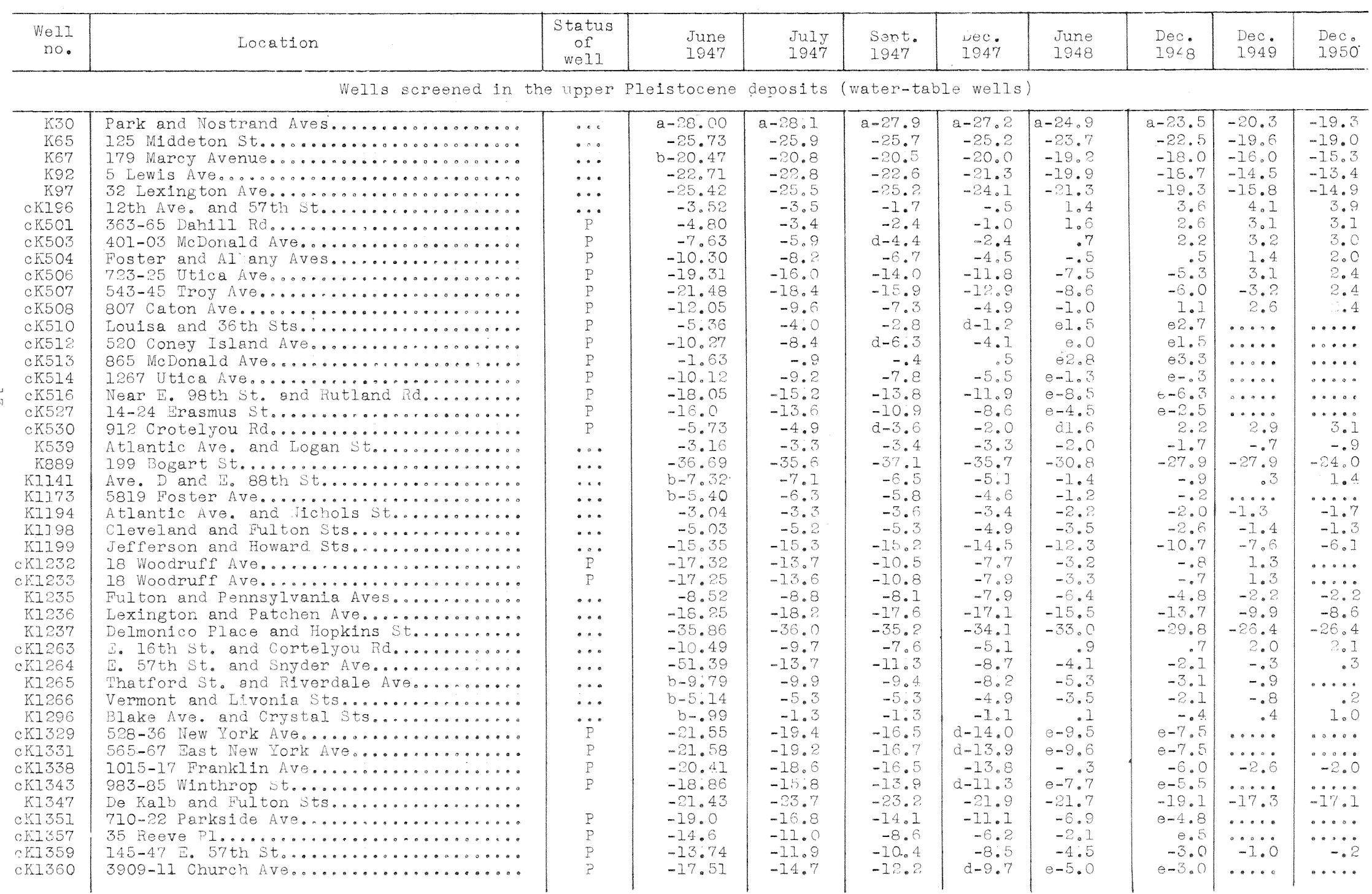




\begin{tabular}{|c|c|c|c|c|c|c|c|c|c|c|}
\hline 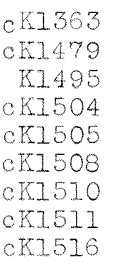 & 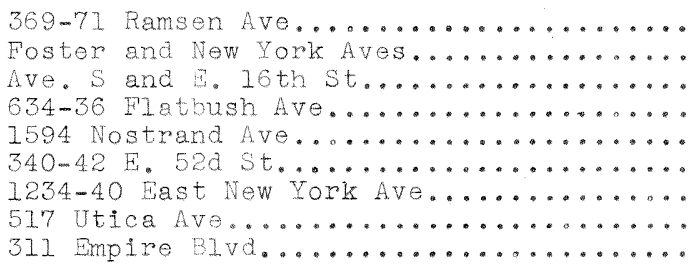 & $\begin{array}{r}P \\
P \\
N P \\
N P \\
N P \\
N P \\
N P \\
N P \\
P\end{array}$ & $\begin{array}{r}-15.99 \\
a-9.92 \\
b 2.35 \\
-18.11 \\
-14.14 \\
-16.15 \\
-15.97 \\
a-20.32 \\
-21.56\end{array}$ & $\begin{array}{r}-13.5 \\
a-7.7 \\
2.0 \\
-16.8 \\
-12.6 \\
-14.0 \\
-14.9 \\
a-18.4 \\
-19.0\end{array}$ & $\begin{array}{r}-11.8 \\
a-6.2 \\
2.1 \\
a-13.9 \\
-11.6 \\
-12.6 \\
-13.7 \\
a-16.0 \\
-16.7\end{array}$ & $\begin{array}{r}-9.8 \\
a-4.2 \\
2.7 \\
-10.8 \\
-7.8 \\
d-10.8 \\
-11.9 \\
a-13.2 \\
i-11.5\end{array}$ & $\begin{array}{r}e-5.9 \\
a-.1 \\
3.3 \\
e-6.8 \\
-2.6 \\
e-6.1 \\
-8.9 \\
e-9.0 \\
f-8.1\end{array}$ & $\begin{array}{r}e-3.7 \\
a 1.2 \\
3.6 \\
e-4.5 \\
e-.5 \\
e-4.0 \\
-8.5 \\
e-6.5 \\
-6.5\end{array}$ & $\begin{array}{r}\cdots \\
\cdots \\
2.8 \\
\cdots \\
\cdots \\
\cdots 3 \\
-3.8 \\
-3.1\end{array}$ & $\begin{array}{r}\cdots \\
\cdots \\
3.2 \\
\cdots \\
\cdots \\
\cdots \\
-3.0 \\
\cdots \\
-2.5\end{array}$ \\
\hline $\begin{array}{l}Q 1089 \\
Q 1090 \\
41223 \\
Q 1224 \\
Q 1252 \\
Q 1253 \\
Q 1254 \\
Q 1255 \\
Q 1256 \\
Q 1266 \\
\text { Q1281 } \\
41282 \\
41283 \\
Q 1285 \\
41286\end{array}$ & 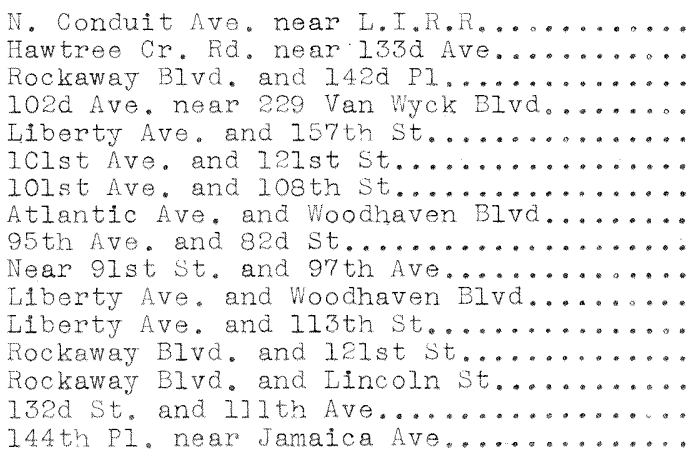 & $\begin{array}{l}\cdots \\
\cdots \\
\cdots \\
\cdots \\
\cdots \\
\cdots \\
\cdots \\
\cdots \\
\cdots \\
\cdots \\
\cdots \\
\cdots\end{array}$ & $\begin{array}{r}1.70 \\
3.19 \\
7.37 \\
6.91 \\
12.12 \\
1.59 \\
-2.59 \\
-5.29 \\
-3.65 \\
2-5.57 \\
-1.75 \\
3.33 \\
6.29 \\
6.29 \\
5.73 \\
9.22\end{array}$ & $\begin{array}{r}7.52 \\
2.93 \\
7.03 \\
6.58 \\
-.00 \\
1.36 \\
-2.74 \\
-5.79 \\
-4.06 \\
--6.25 \\
-2.02 \\
-.08 \\
3.01 \\
5.65 \\
5.41 \\
8.98\end{array}$ & $\begin{array}{r}1.09 \\
2.40 \\
6.34 \\
6.54 \\
11.23 \\
-3.99 \\
-6.26 \\
-4.45 \\
2-4.54 \\
-2.54 \\
.10 \\
2.27 \\
5.79 \\
4.74 \\
8.23\end{array}$ & $\begin{array}{r}1.50 \\
2.42 \\
5.94 \\
6.26 \\
11.33 \\
1.11 \\
-3.04 \\
-5.50 \\
-4.04 \\
a-4.02 \\
-2.18 \\
-.72 \\
2.43 \\
5.48 \\
5.01 \\
8.20\end{array}$ & $\begin{array}{r}1.69 \\
2.98 \\
6.55 \\
7.08 \\
12.86 \\
1.93 \\
-2.28 \\
-4.37 \\
-2.88 \\
a-2.86 \\
-1.26 \\
.14 \\
2.95 \\
5.76 \\
5.48 \\
9.35\end{array}$ & $\begin{array}{r}1.37 \\
2.02 \\
4.65 \\
7.6 \\
12.34 \\
1.62 \\
-2.14 \\
-4.50 \\
-2.96 \\
8-5.27 \\
-1.51 \\
\cdots 1.75 \\
5.54 \\
4.46 \\
9.05\end{array}$ & $\begin{array}{r}1.9 \\
2.2 \\
5.0 \\
3.0 . \\
11.8 \\
1.2 \\
-4.4 \\
-3.4 \\
-2.4 \\
-2.6 \\
-1.3 \\
2.3 \\
2.7 \\
8.6 \\
4.2 \\
8.4\end{array}$ & $\begin{array}{r}2.1 \\
2.2 \\
5.7 \\
\cdots .9 .7 \\
9.7 \\
-3.6 \\
-4.2 \\
-2.8 \\
-3.0 \\
-.9 \\
2.8 \\
2.9 \\
7.0 \\
3.9 \\
7.0\end{array}$ \\
\hline
\end{tabular}

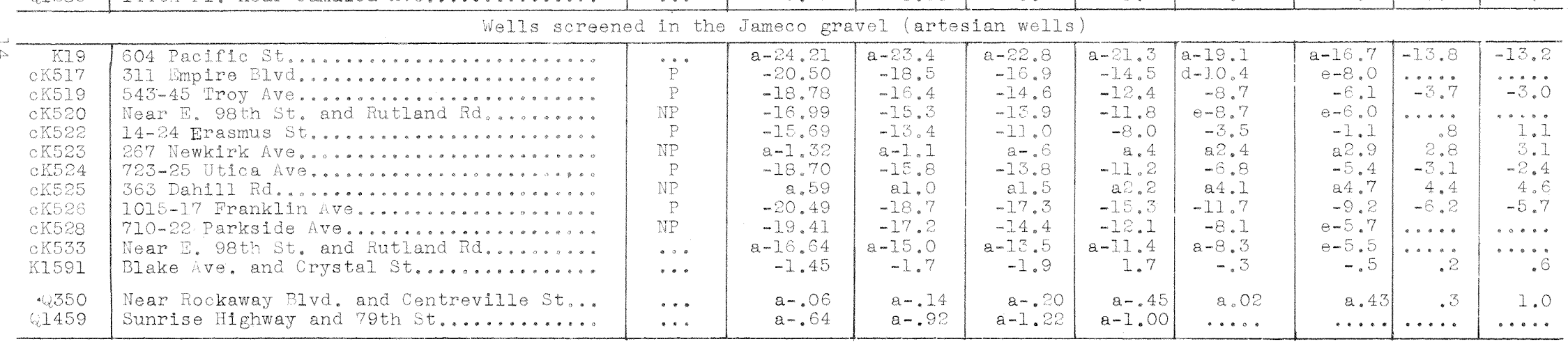

Wells screened in the Lloyd sand member of Raritan formation (artesian wells)

\begin{tabular}{|c|c|c|c|c|c|c|c|c|c|c|}
\hline $\begin{array}{l}\text { CK521 } \\
\text { K1.057 }\end{array}$ & 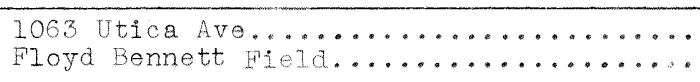 & $\operatorname{NP}$ & $\begin{array}{l}a 3.33 \\
a 8.7\end{array}$ & $\begin{array}{l}2.2 .9 \\
27.8\end{array}$ & $\begin{array}{l}2.9 \\
27.2\end{array}$ & $\begin{array}{l}23.3 \\
28.4\end{array}$ & $\begin{array}{l}24.5 \\
98.9\end{array}$ & $\begin{array}{l}25.9 \\
29.7\end{array}$ & $\begin{array}{l}5.1 \\
8.5\end{array}$ & $\begin{array}{l}6.3 \\
9.2\end{array}$ \\
\hline 6543 & Rockaway Beach Blva, and Beach Iloth St.. & $\ldots$ & 28.2 & a 7.2 & 23.9 & a 3.3 & 98.9 & 99.3 & 9.1 & 9.3 \\
\hline
\end{tabular}

a Water-level measurements from observation well equipped with water-stage recorder.

b Water-level readings made during last week in June 1947 .

C Observation wells in franchise area of the New York Water service corp.

d Water level determined from hydrographic plo

f Water level affected by puming in vicinity.

Note: Water-level readings taken during last week of month indicated. Readings listed for June 1947 are for the 30 th, except those marked with $\underline{c}$. 
Table 3.--Recovery of ground-water levels, in feet, in Kings and Gueens Counties, N. Y., from June 1947 to September 1950

[Recoreries computed on the basis of water levels measured on June 30, 1947, after an approximate I2-hr nonpumping period, except for well K135I for which the nonpunping water level on July 1 , 1947 , was use d

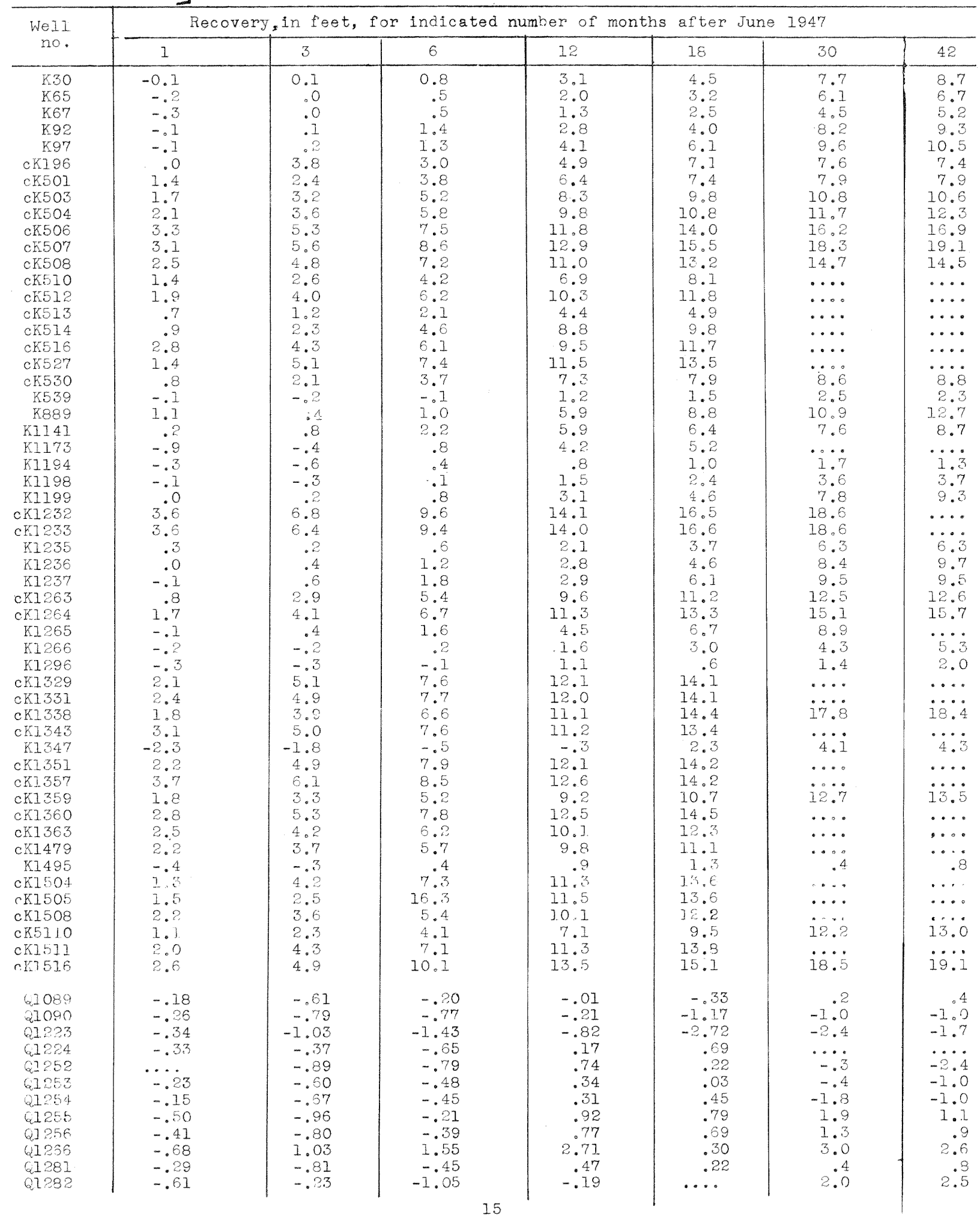


Table 3.--Recovery of ground-water levels, in feet, in Kings and queens Counties, N. Y., from June 1947 to December $1950--$ Continued

[Recovories computed on the basis of water levels measured on June 30, 1947, 3.ter an approximate l2-hr nonpumping period, except for well. Kl351 for which the nonpumping water level on July 1 , 1947, was used

\begin{tabular}{|c|c|c|c|c|c|c|c|}
\hline \multirow{2}{*}{$\begin{array}{c}\text { Well } \\
\text { no. }\end{array}$} & \multicolumn{7}{|c|}{ Recovery, in feet, for indicated number of months after June 1947} \\
\hline & 3 & 3 & 6 & 12 & 18 & 30 & 42 \\
\hline $\begin{array}{l}Q 1283 \\
21284 \\
01285 \\
01286\end{array}$ & $\begin{array}{r}-0.28 \\
-.64 \\
-.32 \\
-.24\end{array}$ & $\begin{array}{r}-1.02 \\
-.50 \\
-.99 \\
-.99\end{array}$ & $\begin{array}{r}-0.86 \\
-.81 \\
-.72 \\
-1.02\end{array}$ & $\begin{array}{r}-0.34 \\
-.53 \\
-.25 \\
. .13\end{array}$ & $\begin{array}{r}-1.54 \\
-.75 \\
-1.27 \\
-.17\end{array}$ & $\begin{array}{r}-0.6 \\
2.3 \\
-1.5 \\
-.8\end{array}$ & $\begin{array}{r}-0.4 \\
.7 \\
-1.8 \\
-2.2\end{array}$ \\
\hline
\end{tabular}

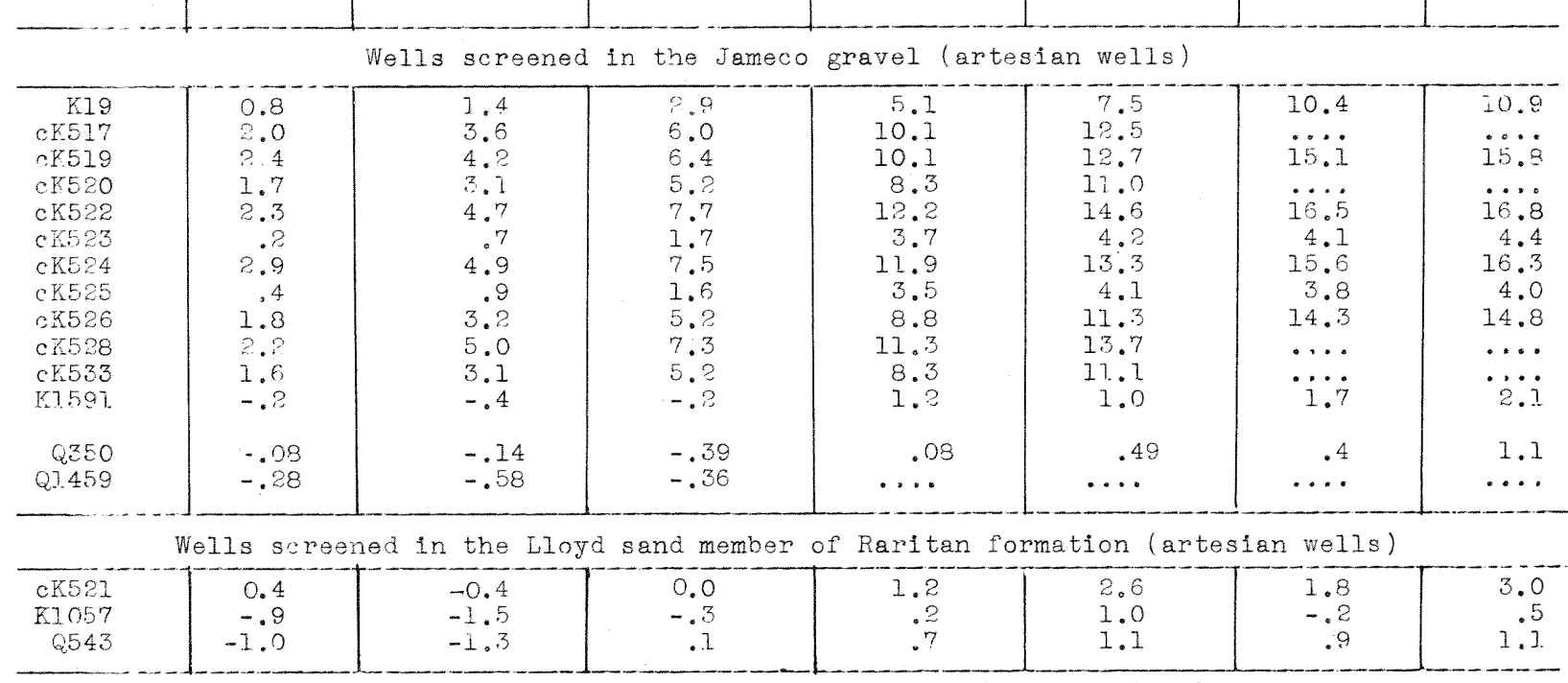

c Observation wells in franchise area of the New York Water Service Corp. 
Table 4.-Ground-water levels, in feet, mean-sea-level datum, in additional wells in Kings County, N. Y., for December 1950 .

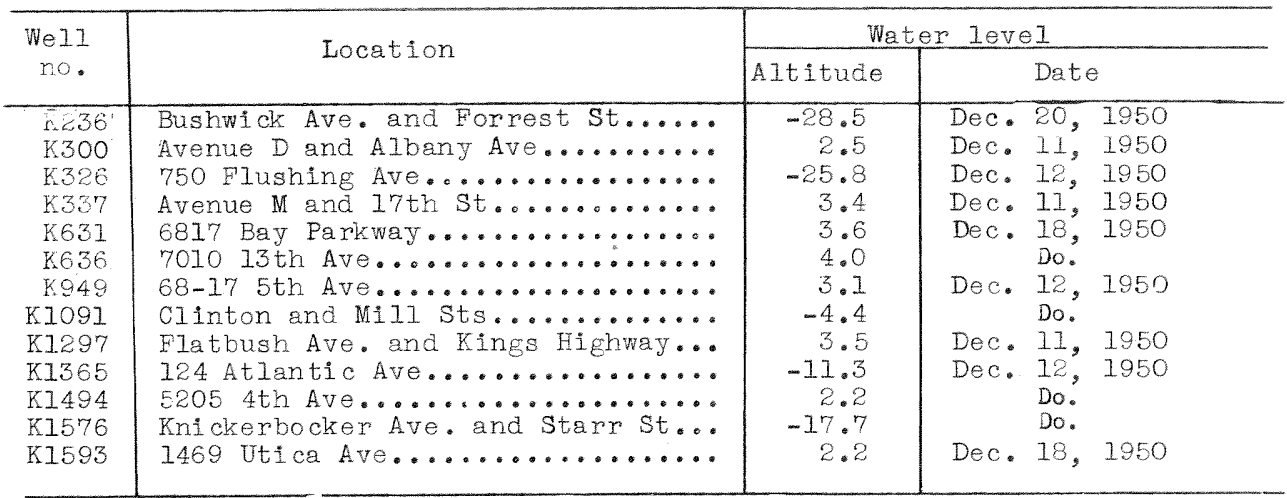

Note: Water-level measurements in above wells made for first time in 1950. This 1ist supplements that in table 2. All wells screened in upper Pleistocene deposits (water-table wells). Altitude, in feet, above or below (-) mean sea level (Sandy Hook datum).

the heavily pumped franchise area of the New York Water Service Corp. in Flatbush; water levels at wells $\mathrm{K} 30$ and $\mathrm{K} 1237$ indi cate trends near the bottom of the so-called crater area in the highly industrialized section of northwestern Brooklyn about $2 \frac{1}{2}$ miles north of Flatbush. Data at well K1266 portray fluctuations 2 miles east of the franchise area and near the Queens County Iine. The trend of water levels in these four wells in Kings County is influenced primarily by pumping and to a much lesser degree by precipitation. In direct contrast, the trend of the average level of the 14 selected wells in Nassau and suffolk Counties reflects the precipitation trend much more closely than the pumping. Previous studies by Leggette (1940), Jacob (1945b), and others emphasize approximate paralleis ism between precipitation and groundwater level trends in central Iong Island.

After the general shut-down of pumping by the New York Water Service Corp. In June 1947 , water levels at these wells recovered rapidly. The rise generally varied inversely with the distance from the center of the area of previous heavy pumpage. At wells K1264 and $\mathrm{K} 30$, gains of $15.7 \mathrm{ft}$ and $8.7 \mathrm{ft}$, respectively, were recorded during the $3 \frac{1}{2}-y r$ period ending in December 1950; at well K1266 the rise was much smaller. On the other hand, the average level of the 14 selected wells portraying the precipitation pattern showed a net drop during this same period.

\section{Artesian Formations}

In the early $1930^{\prime} \mathrm{s}$ as much as $16 \mathrm{mgd}$ was withdrawn from the artesian formations within the franchise area of the New York Water Corp.

Later this pumpage was reduced gradually to less than 7 mgd at the time of the general shut-down in June 1947 because of the increas- ing salinity of the artesian water. (See fig. 2 and table 1.) The chloride content was so high at some of the artesian wells after a few years that they were operated only during periods of emergency. All but one of the artesian wells constructed for the New York Water Service Corp. were screened in the Jameco gravel ( $\mathrm{flg}$. 8); well K52l was in the Lloyd sand member of the Raritan formation.

An over-all recovery of water levels, as shown in figure 9 and in table 3 , certanIy not equal in horizontal directions, folm lowed the cessution of pumping in the artesiar formations. In general, the rate of recovery, the total rise, and the altitude of water levels in the Jameco gravel corresponded closely with those in the water-table welis for the first few months after the shut-down. Monthly hydrographs for pairs of wells at eash of several locations in Flatbush (fig. 10) portray this parallelism of recovery of water levels in the two adifers. After the first vear, primarily because of the more immediate effect of recharge to the shallow aoulfers by precipitation, the water table in general rose at a slightly faster rate than the artesian levels. By the end of 1950 the differ... ence in levels in the pairs of wells at the several sites was not more than $2 \mathrm{ft}, 3 \frac{1}{2}$ yr after the shut-down.

Profiles of the plezometric surface (flg. 11) along cross sections indicated on the index map (fig. 8) are plotted for several dates from June 1947 to December 1950. These illustrate that (I) the largest recovery occurred in areas where the Jameco gravel was pumped heavily previousiy, (2) the cone of recovery expanded rapidly northwestward from well K.19 and somewhat more slowly southwestward to and beyond wells $K 523$ and K525, (3) the smallest net change in water levels in the Jameco gravel was measured east of Flatbush near the Kinss-queens county line at wells KI591, Q1459, and 2350 , and (4) the 


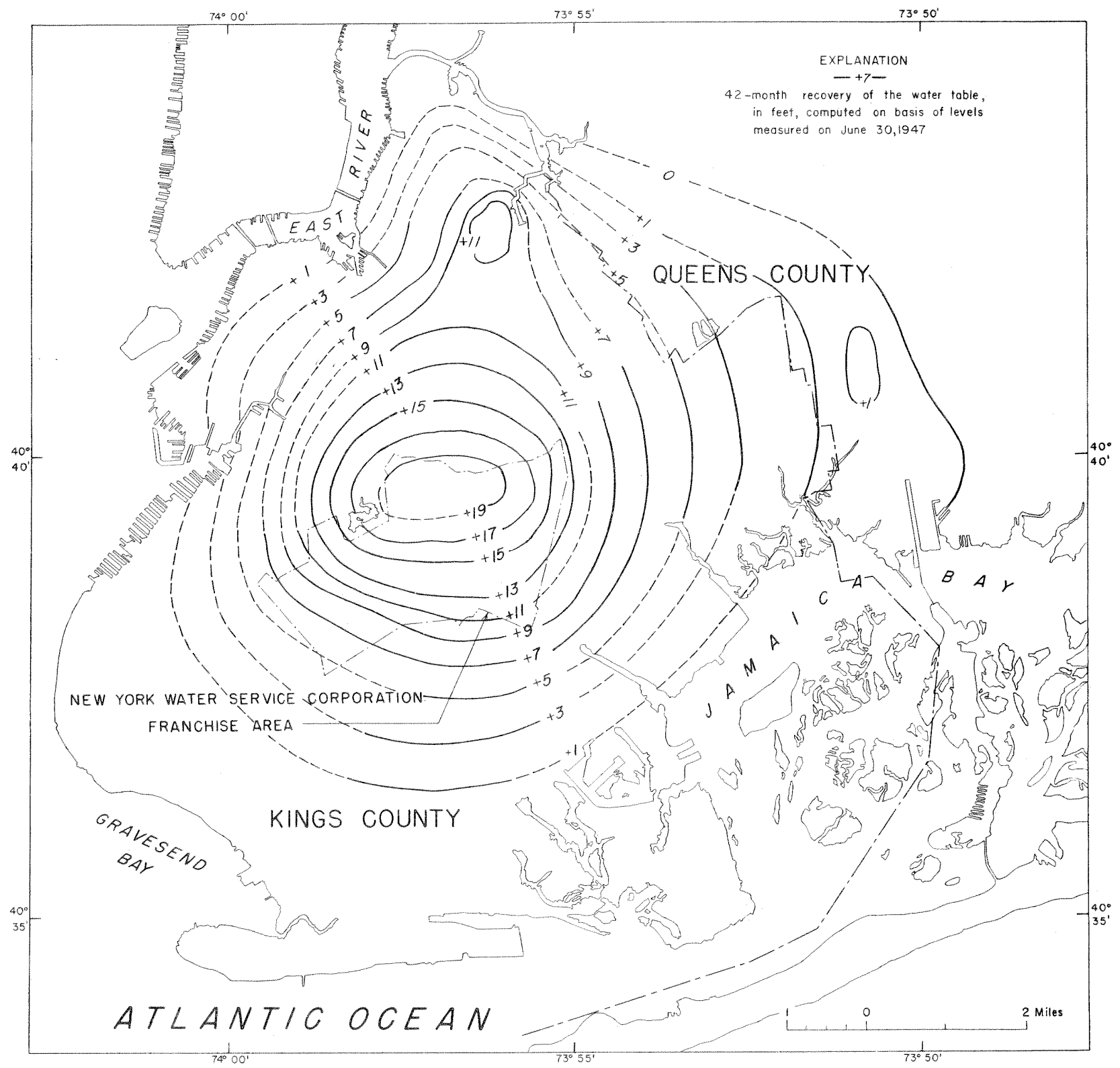

Figure 5.-.-Recovery of water table in Kings and Queens Counties, N. Y., from June 1947 to December 1950. 


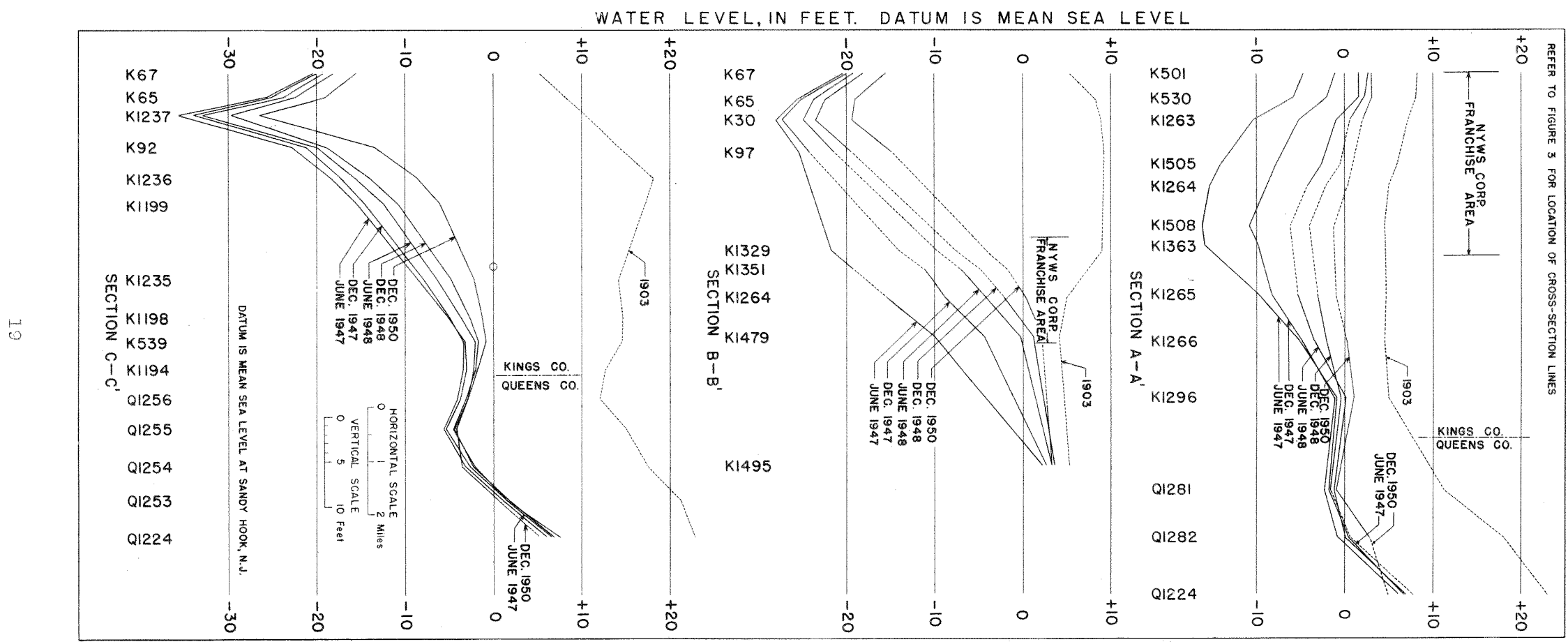

Figure 6.--Profiles of water levels in Kings and Gueens Counties, N. Y., in 1903, 1947-50. 
gouifer in which we11 K521 was screened was only remotely connected hydraulically with the principal beds of the Jameco gravel.

The relatively small number of artestan wells and their inadequate distribution geographically fail to provide sufficient basic data for accurate contouring of plezometric levels and recovery. However, a piezometric map and a map showing recovery of water levels in the Jameco gravel undoubtedly, as explained above, generally would be similar - -at least in the franchise area of the New York Water Service Corp. - to the water-table contour map (fig. 4) and the recovery map (fig. 5), respectively.

\section{Sumary--Recovery of Water Levels in Brooklyn}

The large recovery of water levels in the water-table and artestan formations in Brooklyn from June 1947 to December 1950 , especially in the Flatbush section and rearby vicinities, is attributed largely to the shut-down of pumping by the New York Water Service Corp. In June 1947. At this time, the total net wi tharawals were reduced more than 50 percent from about $50 \mathrm{mgd}$ to about $23 \mathrm{mgd}$.

However, some of the rise in the water table, perhaps as much as 1 ft and more in some localities, and a small part of the rise of artesian levels in the Jameco gravel express replenishment from precipitation during the 42 -month period ending December 1950. Much of the surface area in northern and western Kings County has been made relatively impervious by the works of man. Yet many relatively pervious areas still remain, especially in the southern and southeastern section of Brooklyn, where recharge from precipitation is appreciable.

In general, water levels continued ris ing without any serious intermption in the northem half of Brooklyn where the were below sea level from June 1947 to December 1950. In southern Brooklyn and especially where the mater table rose above sea level, the highest altitudes were reached during 1948. Since then a slight recession consistent with the orecipitation pattern was observed at many wells.

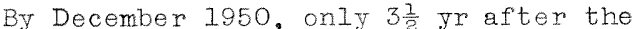
shut-down of pumping, a remarkable improvement in the status of water levels in Brooklyn was noted. The water table was below sea level only in the northem half of Brooklyn where the extent of the crater area, or cone of depression, was continually decreasing. In al1. the net gain in storage in the watertable formations in Brooklyn from June 1947 to December 1950 was about 20 billion gallons. Another 10 billion gallons will fill the present crater in northem Brooklyn to sea level. The increase in storage in the Jameco gravel was much smaller.

The recovery reached westem Queens but was overbalanced by the gradual1y increasing rate of pumping in this adjacent county.
As the average replenishment from precipitation and the laterial inflow from Queens County continue to exceed net withdrawals and out-flow to sea in Brookl yn, the rising trend can be expected to continue-unless pumping is increased appreciably, or a severe drought is experienced on Long Island. However, although the water table may continue to recover for many years, the record high levels of 1903 may never be reached again under natural conditions. The large increase in population and the industrialization and commercialization of the county contributed significantly to the reduction of the pervious lend area, and thus resulted in a permanent decrease of replenishment to the underground aquifers from precipitation.

With the water levels continually recoverIng, subways, cellars, and subcellars that have not been waterproofed at and below sea level may in time be flooded by the rising water table or artesiar levels.

\section{SPECIAI STUDIES}

Previous investigators correlating data on the geology of westem Long Island were confronted with the following perticular questions with respect to the deeper wells and formations in Brooklyn:

1. Are wells K523 and K525 screened in the shallower beds of the Jameco gravel separated hydraulically from its principal beds?

2. Is wel1 K521 screened in the deeper beds of the Jameco eravel or in the Lloyd sand member?

3. Can the continuity of the Jameco gravel from western Queens County to central Kings county be established by pumping or shut-down interference?

The complete shut-down of pumping by the New York Water Service Corp. In June 1947 allowed the collection of very valuable data. which combined with other available information provided more positive answers to these questions.

\section{WelIs K523 and K525 in the Jameco Gravel}

We1Is K523 and K525 in the Jameco gravel, more than 2 miles southwest of the center of the area of pumping from the aquifer (fig. 8), were abandoned in the middie 1930 's after a few years of heavy pumping because of a high chloride content. After June 1947 water levels at these abandoned wells recovered much more slowly than those at the other wells in the Jameco gravel in the franchise area of the New York Water Service Corp.

Geologic, hydrologic, and salinity data when considered together establish the fact that wells $K 523$ and $K 525$ are screened in the principal beds of the Jameco Eravel and that they are artesian wells. The slow rate and small amount of recovery after the general shut-down of pumping in June 1947 suggest (1) somewhat less direct hydraulic connection 


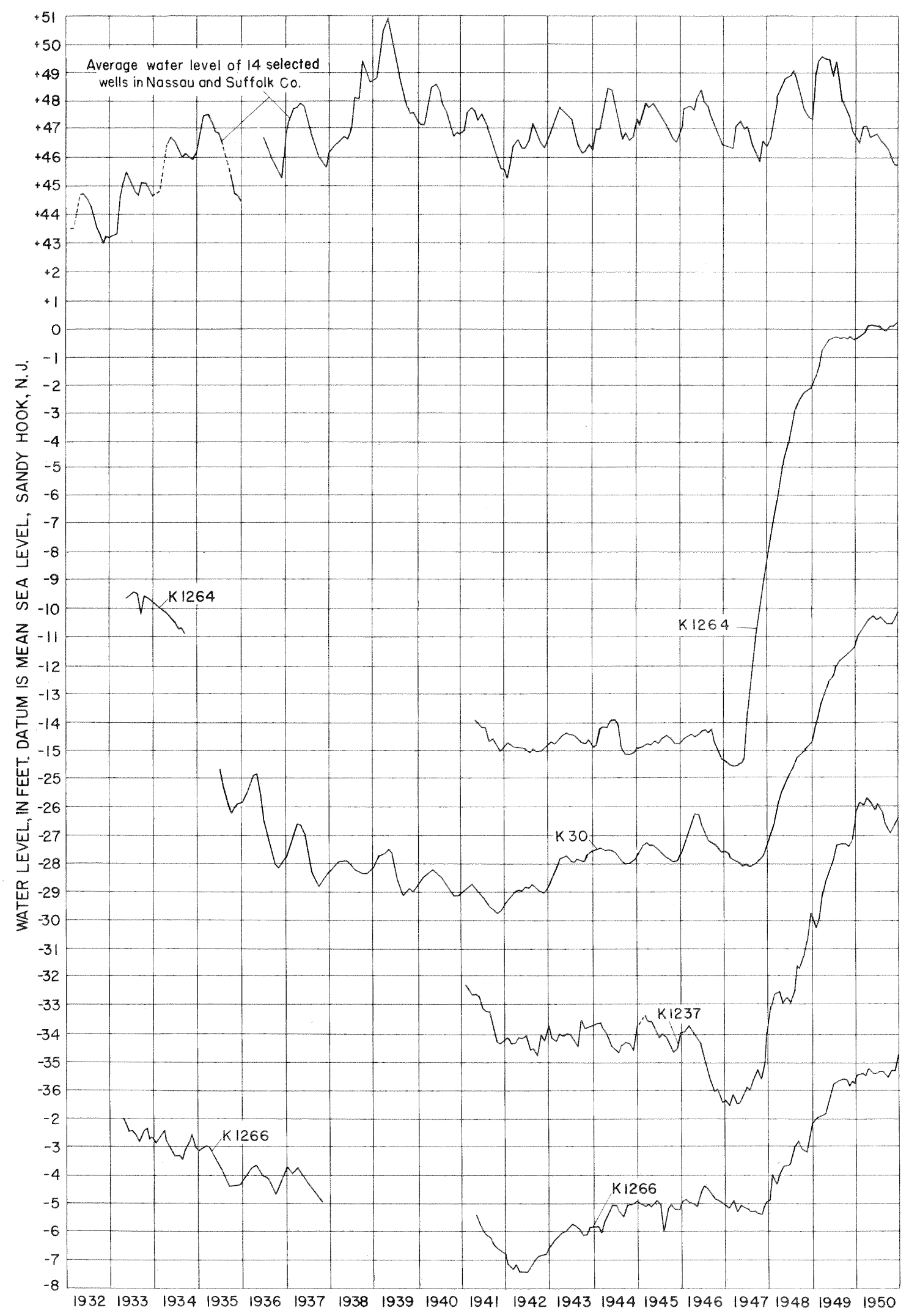

Figure 7.--Monthly water levels in selected water-table wells on Long, Island, N. Y., for 1932-50. 


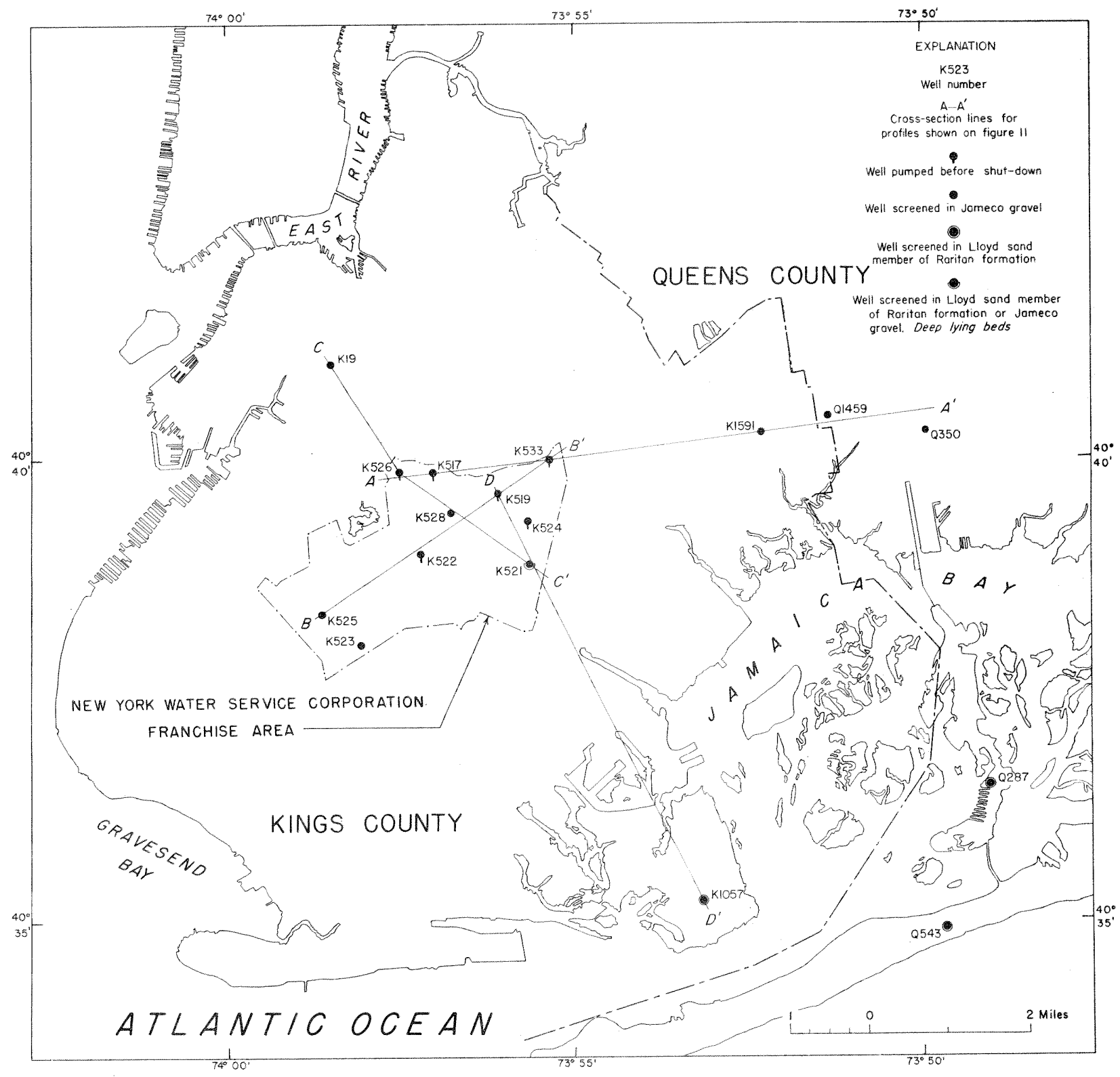

Figure 8.--Index map showing artesian wells and cross-section Iines in Kings and Queens counties, $N$. $Y$. 


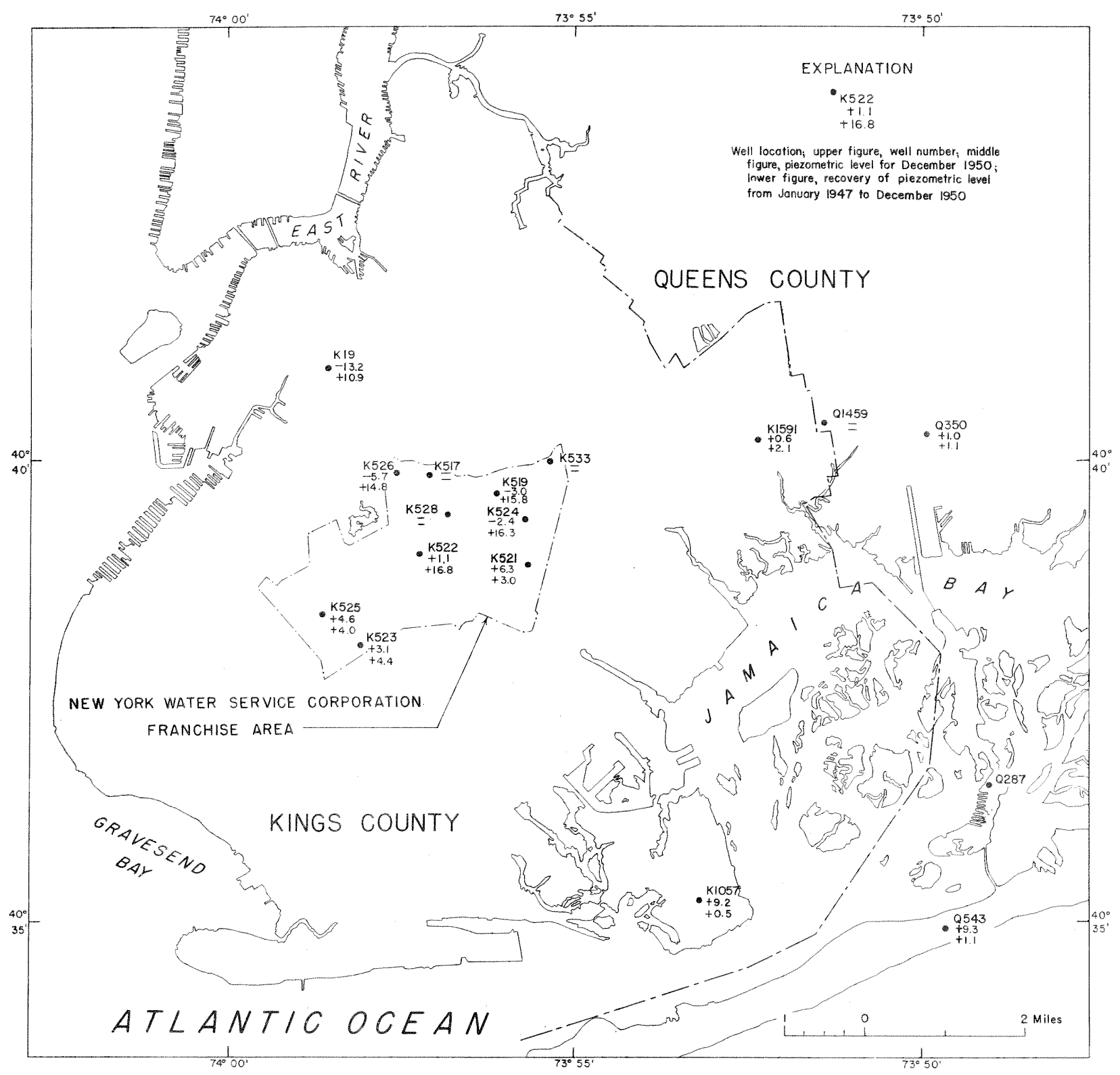

Figure 9. Recovery of water levels in artesian wells in Kings and Queens Counties, N. Y., from June 1947 to December 1950. 


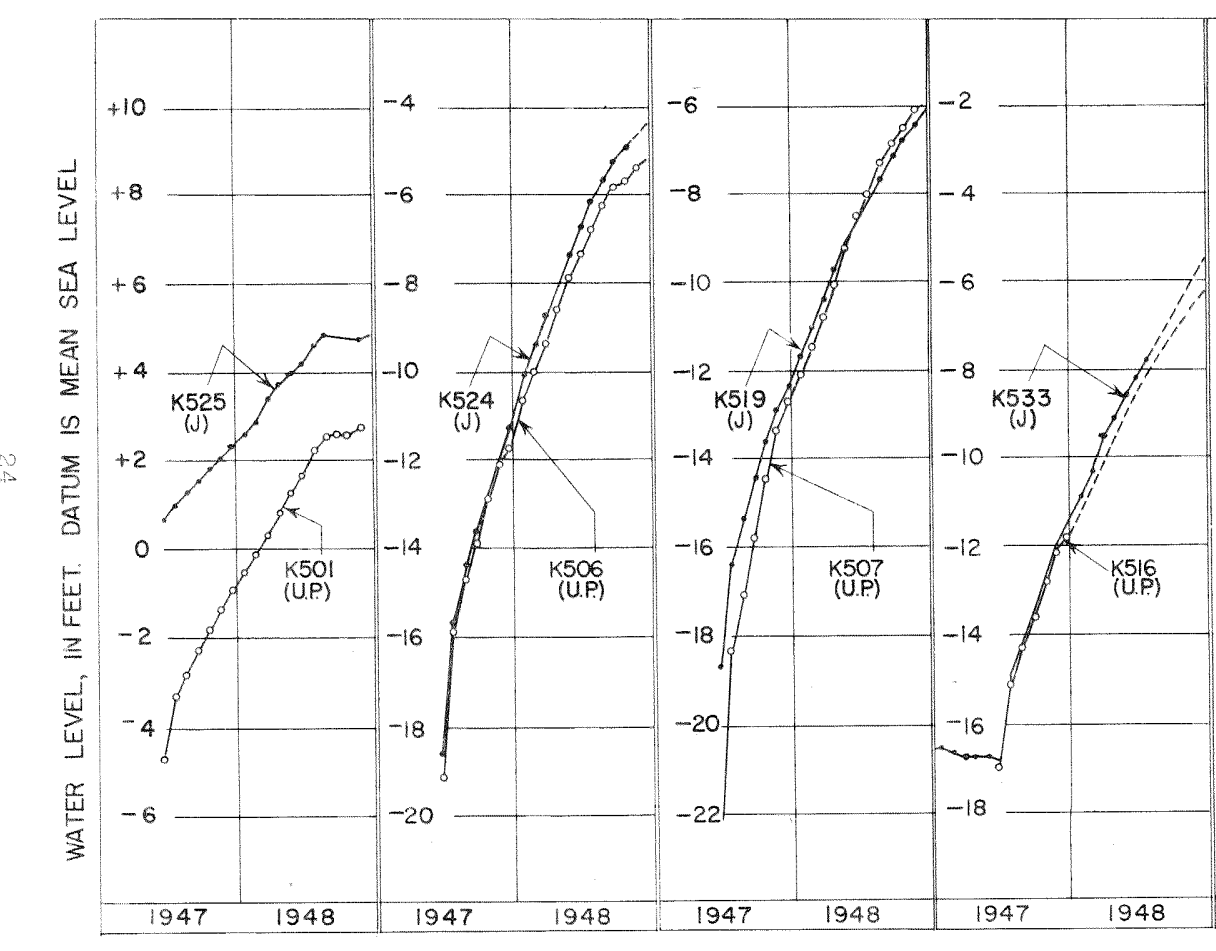

For above pairs of wells, the water-table wells are within

100 feet of the artesian wells. All wells are located in

the franchise area of the New York Water Service Corporation

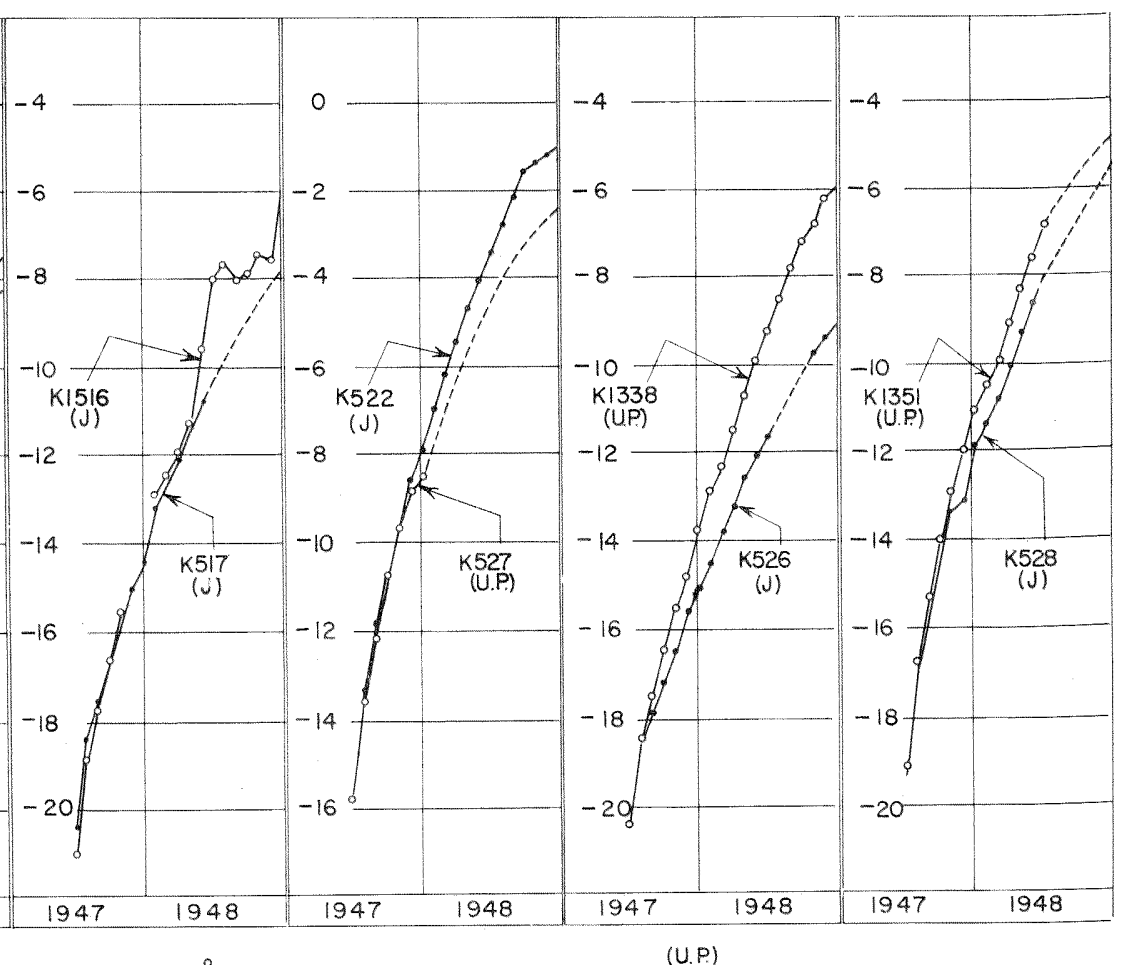

Monthly water level in water-table well

Upper Pleistocene deposits

Monthly water level in artesian well

Jameco gravel

Levels computed on bosis of profiles,
contours, and trend of recovery

Figure 10.--Comparison of water levels in water-table and artesian wells in Kings County, N. Y. 
with the Jameco gravel to the east, (2) and rather indirect hydraulic interconnection. with the overlying water-table deposits. The level in well K525 was about 2 ft higher than that in the nearby shallow water-table well K501, 50 ft away. Moreover, the nonpumping water level in well K525 at aII times was hither than any measured not only in the other wells in the Jameco gravel but also in the water-table formations. This significant hydrologic evidence suggests that the recharge to the Jameco gravel at we1Ls K523 and K525 may originate from the deeper formation, perhaps from the Lloyd sand member of the Raxitan formation.

That weII K525 is antesian is confirmed by the comparison of salinity data. The chloride content of water samples from the nearby shallow well K501 increased at a much slower rate than from well K525 (table 1). The extremely rapid increase in salinity in well K525 when pumped could have occurred only under predominantly artesian conditions-that is when the coefficient of storage was low. Then too, the difference in the rate of increase of salinity in these two adjacent wells screened in separate aquifers indicates that the Gardiners clay, in general, prevented rapid movement of ground water to and from the upper Plesatocene (water-table) deposits.

The above reasoning and conclusions with respect to well K525 apply, in general, to we11 K523.

\section{$\frac{\text { WeII K521 in the Lioxd Sand Member of }}{\text { the Raritan Formation }}$}

Date on piezometrice levels in the Lloyd sand member of the Raritan formation were included in flugres 11 and 12 ormarily to illustrate graphicaliy that the water levels in well K52I were much higher than those measured at wells in the Jameco gravel and that the trend of levels and pattern of flucm tuation for welI K52I corresponded much more closely wh those for well KI057 screened in the Lloyd and member of the Raritan formation.

The piezometric level in well $\mathrm{K} 52 \mathrm{l}$ was at altitudes of 3 to $6 \mathrm{ft}$ above mean sea level for more then a year before and after the shut-down. Thus at all times it was not oniy above the levels in other observation wells an the Jameco gravel but also higher than any level measured in the shallow watertable formations in Brooklyn. only at one observation well in Kings County was a measured level higher than in well K521. That measured Level was in well. KIO5?, 4la miles to the south screened in the Liloyd sand member, strongly suggesting that aquifer as a source of recharge.

of particular significance and importance is the fact that arterian levels computed for a theoretical well in the principal beds of the Jameco gravel at the site of K521 were lower by several feet than those actually measured in weIl K52I since the shut-down. The calculations were baged on avallable water level data for nearby wells sereened in the Jameco gravel and on the hydraulic charm acteristics of this aquifer.
A study of the salinity trend in the artesian wells provides further justification for the classification of well K521 as a well screened in the Lloyd sand member. Three vears after the start of pumping in 1929 the salinity of ground water sampled from weIl K521 had increased from 29 ppm to more than 200 pom. At aII other wells in the Jameco gravel in the vicinity of well K521, the rate of increase was so much slower that salinities of more than 200 ppm were not measured until about 1942, I0 gr later.

No immediate and direct interference was detected at well K521 after the shut-dow of pumping at weII K524 only 1 mile to the north. WeII K521 not only failed to respond to the general recovery of plezometric levels in the Jameco gravel but also indicated an opposite trend more consistent with that in the Liloyd sand member. On the other hand, the shut-alown of pumping in November 1949 from weIl K619, screened in the Lloyd sand member, was reflected in we $11 \mathrm{~K} 52 \mathrm{I}$ located 2 miles to the west.

In view of all the hyarologic, salinity, and geologic evidence, it is concluded that weII K521. reflects much more closely the behavior pattern of welIs acreened in the LIoyd sand member than of those in the Jameco gravel, and for all practical purposes it can be considered as a weIl screened in the LIoyd sand member.

\section{Mutual Interference in the Jameco Gravel}

In an earlier unpublished report, Ferris (1942) noted marked interference between many wells in the Jameco gravel in central and northwestem Brooklyr. He also observed mutual interference between several wells in the Jameco gravel in southern queens County; such an interconnection was then traced by him step by step from southem Queens county westward to the wells in the Jameco gravel in eastem Kings County pumped infrequently by the New York Clty Department of Water Supoly, Gas and Plectrictty at the New Lots pumping station. Hovever, the final connect ing Ink of hydraulic continuity in the Jameco gravel was not established by Ferris because of the lack of data for this purpose.

It was therefore hoped that the complete shut-down of pumping by the New York Water Service Corp. on June 1947 would provide definite information as to the extent, if any, of the hydraulic comection between the beds of the Jameco gravel in Kings and queens Counties. For this purpose three recorders were instalied before the shut-down of wells K1591, Q1459, and Q550 near the Kings-Queens County Iine to intercept any possible effect resulting from the laree reduction of pumping from the Jameco gravel in central Brooklyn.

Geologic evidence points to the unquestionable presence and the continulty of the Jameco gravel from Kings to Queens County. However, the Gardiners clay in easterm Kings Count overlying the Jameco gravel was estab lished by correlation studies (De Laguna, 1948; Suter and others, 1949) as being more sandy than clayey. This suggests the possibility of a more direct hydraulic interm 


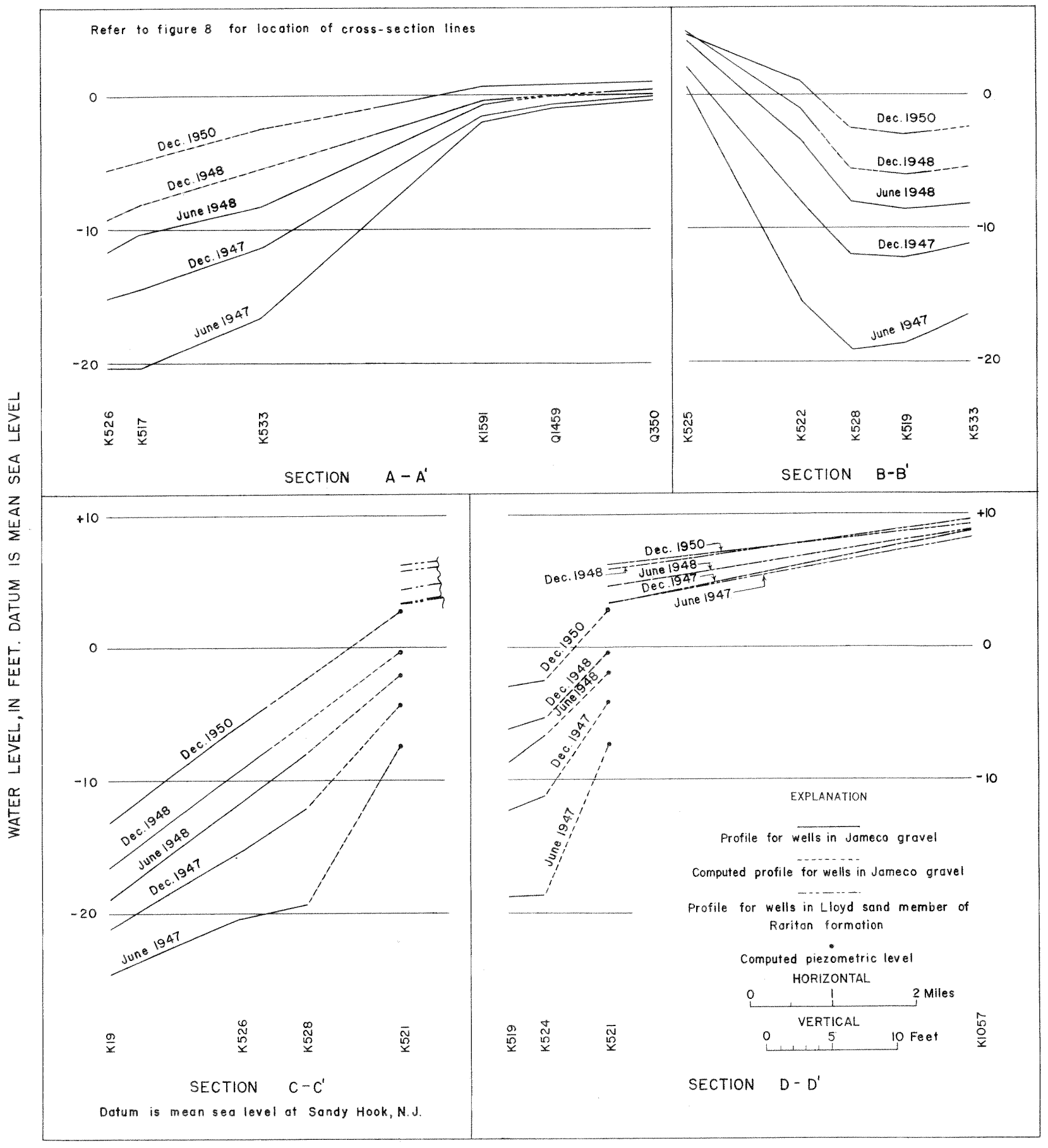

Figure 11..-Profiles of artesian levels in Kings and Queens Counties, N. Y., in 1947, 1948, and 1950. 


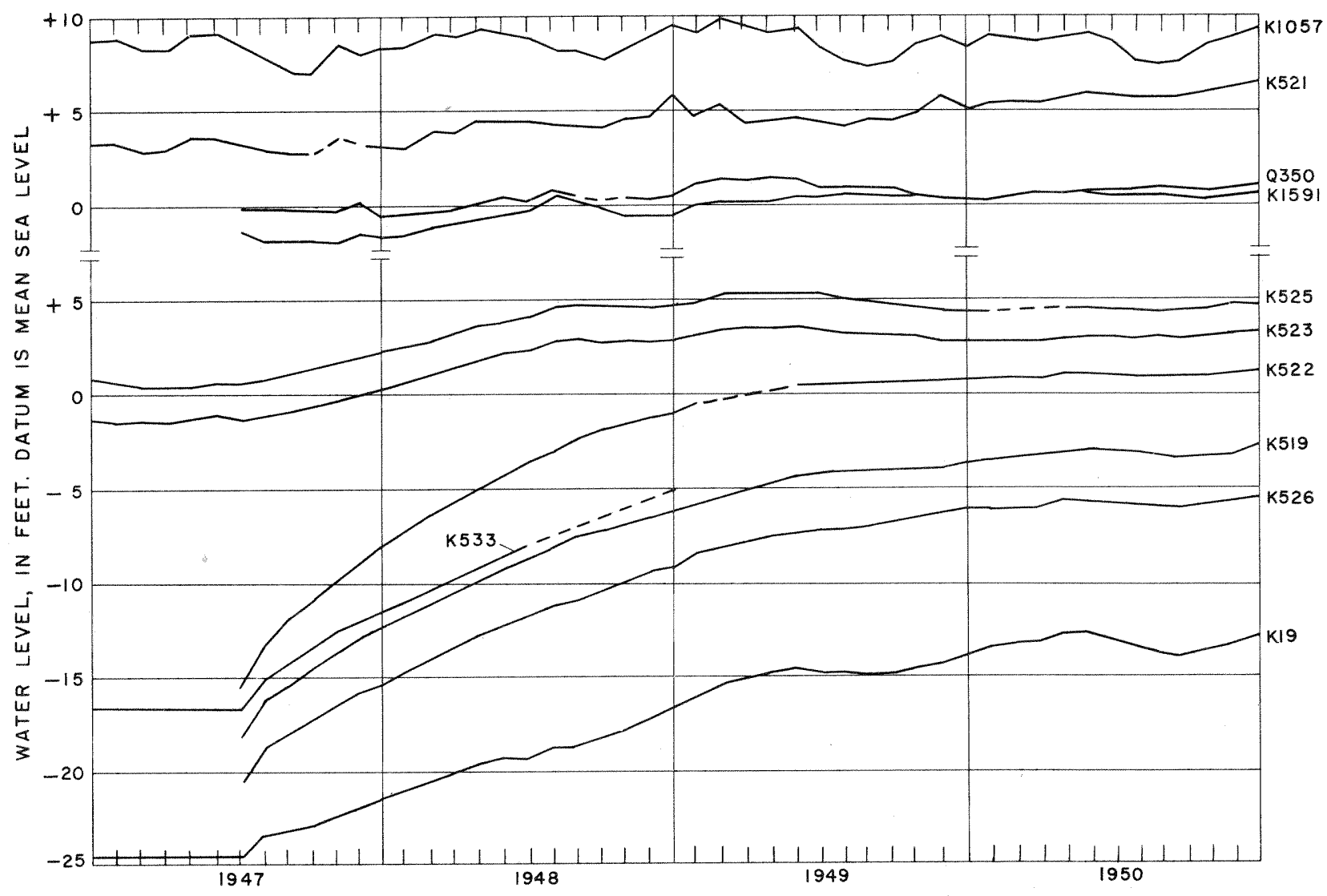

Figure 12.-.-Hydrograph showing monthly water levels in artesian wells in Kings and Queens Counties, N. Y., during 1947-50. 
connection of the Jameco gravel with the overlying water-table deposits. Hydrologic evidence obtained before and since the shutdown in 1947 provides the following support to this supposition as (1) The cone of recovery in the Jameco gravel expanded eastward from Flatbush to Queens County nofaster than that in the shallower water-table deposits, and (2) the trend and luctuation of water levels in the two aquifers at the New Lots pumping station reflect very closely the precipitation pattern as indicated at weIIs K1296 and KI591 in tables 2 and 3 .

Thus the attempt to define the continuity of the Jameco gravel by the recovery of water levels resulting from the large shut-down in pumping failed because the Jameco gravel functions more as a water table and less than an artesian aquifer in eastem Brooklyn. However, the fact that the Jameco gravel was connected almost directly hydraulically with the upper Pleistocene deposits was established instead.

\section{SAEE WITHDRAWAL}

For several years before the complete shut-down of pumping by the New York Water Service Corp., total net withdrawals in Kings County for all uses averaged more than $60 \mathrm{mga}$. At this rate of pumping, water levels remalned below sea level and the salintty of ground water increased. Such conditions defined overdevelopment. After June 1947, when the total net pumpage was reduced to about $23 \mathrm{mgd}$, replenishment exceeded withdrawal. In general, water levels recovered rapidly and were still. rising practically everywhere in Brooklyn in December 1950. It can be concluded that the safe withdrawal of water-bearing formations in Brooklyn is between $23 \mathrm{mgd}$ and $60 \mathrm{mgd}$.

The net replenishment to storage attributable to the recovery in the water-table aquifer in $3 \frac{1}{2}$ yr was about 20 billion galions, representing a rate of about $17 \mathrm{mgd}$. The increase in storage in the Jameco gravel was much less. The total accretion rate from precipltation and underflow from Queens county is the sum of the average rate of net pumping ( $23 \mathrm{mgd}$ ) and of increase in storage (17 $\mathrm{mgd}$ ), which totals to about $40 \mathrm{mgd}$. On this basis, with an assumed safety factor of 25 percent, the safe witharawal of the water-bearing formations. in Brooklyn is about $30 \mathrm{mgd}$ for a sufficiently weI1-planned and coordinated development in the county. In this cornection it is interesting to note that suter (1937, p. 11) calculated the highest degree of development in 1936 as 40 mgd for Kings county.

Most of the present pumping in Brooklyn is concentrated in the northem sections, where the water table is still below sea level. The safe withdrawal from this area is probably not much more than the present net withdrawal of about 13 mgd. The remaining 17 mgd, or about 9 mgd more than the present pumpage, can be pumped from southem Brooklyn where the water levels are now above sea level.
The Jameco gravel was highly overdeveloped by the New York Water Service Corp. at 16 mgd in 1933. When withdrawals from this artesian aquifer were reduced to average 10 mgd during the period 1941-47, the salinity of ground water in central Brooklyn kept increasing. Experience thus shows that most of the withdrawals in Brooklyn must be made from the shallow water-bearing formations and that the safe withdrawal from the Jameco gravel is not much more than 5 mgd.

The present ever-increasing concentration of population in many sections in the United States demands comprehensive and integrated planning of surface- and ground-water development on a regional basis. To an increasing extent through the years, engineers have proposed recharging underground aquifers with some of the excess surface water that cannot be detained in surface-water reservoirs during certain seasons of the year. In this connection it is of interest that the capacity of the ground-water reservoirs of only the watertable deposits in Brooklyn (assuming sea level as approximately the high flow line) was computed to be at least 200 billion gallons. If as little as 10 percent, representing a potential of about 20 blilion gallons, can certainly be realized as usable storage, the availability and utilization of this water can play at least a minor role in any integrated planning.

\section{CONCLUSIONS}

The expanded program for recording the recovery of water levels in Brooklyn from June 1947 to December 1950 , and the over-al1 study and integration of hydrologic, geologic, salinity, and pumpage data provided much basic information pertaining to the hydrology and geology of western Long Island, which could not have been obtained otherwi se. Hydrologic answers to some geologic problems were obtained.

This report offers the following findings and conclusions:

1. The crater area or the huge cone of depression in Brooklyn was more than twothirds refilled in the $3 \frac{1}{2}-y r$ period after the shut-down of pumping about $27 \mathrm{mgd}$ of pumpage by the New York Jater Service Corp. in central BrookIyn. By December 1950, the water table recovered appreciably and was below sea level only in northern Brooklyn where the cone of depression was decreasing gradually.

2. The improvement of ground-water conditions in Brooklyr augmented very Iittle the aval lable ground-water supplies in the franchise area of the Woodhaven sec.. tion of the New York Water Service Corp. in western queens County. The recovery of as much as $19 \mathrm{ft}$ in central Brooklyn and as little as 1 ft around the perimeter of the county extended into Queens County, but was overbalanced by the gradually increasing pumping in Queens County. 
3. The landward advance of salt water in the water-bearing formations, and particularly in the Jameco gravel, an artesian formation, was decelerated in 1947. Under normal conditions many years will elapse before the underground supplies in Brooklyn are entirely fresh.

4. The safe witharawal at the present time is ascertained at about $30 \mathrm{mgd}$, if pumpage is distributed equally throughout the county and most of the withdrawels are made from the shallow water-bearing formations.

5. Indirect hydraulic interconnection of the water-table deposits with the Jameco gravel was verified in central Brooklyn. Throughout the years, ground water percolated downward or upward through the Gardiners clay, depending on the relation of water levels in these two main aquifers in Kings County.

6. Geologic continuity of the Jameco gravel from Kings into Queens County was accepted. But near the Queens County line in eastern Brooklyn the Jameco gravel appeared to have a more direct hydraulic connection with the shallower a oufer and thus functioned much more as a water-table than as an artesian aquifer.

7. No positive substantiation of any principal hydraulic interconnection of the Jameco gravel with the Lloyd sand member of the Raritan formation was observed from the detailed studies. The high static level at well K525 suggests that the recharge to the Jameco gravel where this well is screened could have its source in the deeper Lloyd sand member.

8. Hydrologic, geologic, and salinity evidence defined well K521 as screened in the Lloyd sand member of the Raritan formation.

\section{REFERENCES CITED}

Burr, W. H., Hering, R., and Freeman, J.R. 1904, Report of the Commission on additional water supply for the City of New York: New York, Martin B. Brown Co.

De Iuguna, Wallace, 1948, Geologic correlation of $10 \mathrm{gs}$ of well's in Kings count $y$, N. Y.: New York State Water Power and Control Comm. Bull. GW-17.

Ferris, J. J., 1942, The mutual interference of artesian welis ending in the Jameco gravel on Long Island, N. Y. (unpublished report in files of U.'S. Geol. Survey).
Jacob, C. E. 1944, Notes on determining permeablisty by pumping tests under water-table conditions (mimeographed report in illes of U. S. Geol. Survey).

Jacob, C. E. 1945 a, The water table in the westem and central parts of Long Island, N. Y.: New York State Water Power and Control Comm. BuII. GW-12.

Jacob, C. E., 1945 b, Cormelation of groundweter levels and preopitation on Long Island, $N$. $Y_{\text {: }}$ New York State Water Power and Control Comm. BuIl. GN-14.

Leggette, R. M., 1940, Section on Long Island, N. Y., In Water levels and artesian pressure in observation wells: U. S. Geol. Survey Water-Supply Paper 867.

Suter, Russe11, 1937, Englneering report on the water supplies of Long Island, N.Y.: New Yonk State Water Power and Control Comm. Bull. GW-2.

Suter, Russe11, De Laguna, Nallace, and Perlmutter, N. M., 1949, Mapping of geolow gic fomations and aquifers of Long Island, N. Y: New York State Water Power and Control Comm. Bull. GW-18.

Thels, C. V., 1935, The relation between the lowering of the piezometric surface and the rate of discharge of a well using ground-water storage: Am. Geophys. Union Prans, vol. 16, pp. 519m524.

Thompson, D. G., and Leggette, R. M., 1936, Withdrawa le of ground water on long Island, N. Y.: New York State Water Power and Control Comm. GW-I.

Wiggin, T. H., Sanborn, J. F., and Brush, W. W. 1933, Maps, profiles, and supporting data sheets in connection with city of New York's application 681 to the New York State Water Power and Control Comm. Exhibits $A$ and $J, N, Y$. 
